\title{
Alternative Fuels for Combined Cycle Power Plants: An Analysis of Options for a Location in India
}

\author{
Guido Marseglia ${ }^{1,2,3, *}$, Blanca Fernandez Vasquez-Pena ${ }^{2}$, Carlo Maria Medaglia ${ }^{1}$ \\ and Ricardo Chacartegui ${ }^{2}(1)$ \\ 1 Research Department, Link Campus University of Rome, Via del Casale di San Pio V, 44, 00165 Rome, Italy; \\ c.medaglia@unilink.it \\ 2 Department of Energy Engineering, University of Seville, 41004 Seville, Spain; \\ blanca.fernandezvp@gmail.com (B.F.V.-P.); ricardoch@us.es (R.C.) \\ 3 Instituto de Matemáticas de la Universidad de Sevilla, (IMUS), Universidad de Sevilla, \\ Avenida Reina Mercedes, 41012 Seville, Spain \\ * Correspondence: g.marseglia@unilink.it
}

Received: 2 March 2020; Accepted: 15 April 2020; Published: 20 April 2020

\begin{abstract}
The Sustainable Development Goals 2030 Agenda of United Nations raises the need of clean and affordable energy. In the pathway for more efficient and environmentally friendly solutions, new alternative power technologies and energy sources are developed. Among these, the use of syngas fuels for electricity generation can be a viable alternative in areas with high biomass or coal availability. This paper presents the energy, environmental and economic analyses of a modern combined cycle plant with the aim to evaluate the potential for a combined power plant running with alternative fuels. The goal is to identify the optimal design in terms of operating conditions and its environmental impact. Two possible configurations are investigated in the power plant presented: with the possibility to export or not export steam. An economic analysis is proposed to assess the plant feasibility. The effect of the different components in its performance is assessed. The impact of using four different syngases as fuel is evaluated and compared with the natural gas fuelled power cycle. The results show that a better efficiency is obtained for the syngas 1 (up to $54 \%$ ), in respect to the others. Concerning pollutant emissions, the syngas with a GHG impact and lower carbon dioxide $\left(\mathrm{CO}_{2}\right)$ percentage is syngas 2 .
\end{abstract}

Keywords: Sustainable Development Goals; clean energy; alternative fuels; combined cycle power plant; numerical modelling; biomass

\section{Introduction}

\section{Research Background}

Nowadays, the concern for climate change and the limited availability of fossil fuel sources are pushing research to focus on sustainable energy resources. Taken as a reference, 1990 emission limits of Greenhouse Gases (GHGs) concentrations should decrease to 50\% until 2050 [1-3]. On this pathway, different policies have been defined in favor of energy production from clean sources [4-6] to support Sustainable Development Goals (SDGs) [7].

The optimization of energy production systems including heat, cold and gas, assumes today a fundamental role in the electricity sector [8-11].

In recent years, combined cycle power technologies (CCPP) are widely used as energy production systems because of their high global efficiencies [12-14] and lower environmental impact than other conventional technologies [15-22]. Among other benefits of CCPP compared to other fossil fuel technologies are smaller investments per $\mathrm{kW}$, faster construction and higher operation flexibility [23]. 
In CCPP performance analysis, most of the approaches are based on the principle of energy conservation [24-28]. Ersayn et al. [29] investigated the energy and exergy performance of a CCPP as a function of its components and modifications adding new components, obtaining an improvement of first and second law efficiency, respectively, from $45 \%$ to $56 \%$ and from $24 \%$ to $50 \%$. Kotowicz and Brzeczek [30] proposed a methodology to improve the performance of a CCPP. It is based on the improvement of gas turbine features, and to consider another steam cycle. Recent studies analyze key parameters and operation conditions to optimize CCPP systems [31]. Jahangiri et al. [32] developed exergy, thermodynamical and economic analyses based on the effect of a flue gas injection system. Kilani et al. [33] analyzed the effect of two applications of steam injection within the combustion chamber. They obtained that with an adequate steam injection process which can improve the overall cycle efficiency up to $6 \%$. Ganjehkaviri et al. [34] developed a thermodynamic modelling of a CCPP under different designs.

A proper numerical model must be used for a correct evaluation of CCPP performance [35]. Different commercial tools, as GateCycle, Aspen or Thermoflex, can be used to implement this kind of numerical analysis. Liu et al. [36] developed a simulation of a combined cycle gas turbine power plants using Aspen HYSIS software package. They showed a comparison between the results obtained from two simulation tools (Aspen HYSYS and GateCycle).

The main Operational Expenditure (OPEX) in a CCPP is fuel. The use of alternative sustainable fuels is of high interest for supporting CCPP's sustainability and viability. The use of alternative fuels affects the operation conditions of gas turbines and components [37-39].

Biogas, as an alternative fuel to natural gas, has a lower laminar flame speed, a reduced fuel range, higher requirement energy ignition, and a higher auto-ignition temperature $[40,41]$. These features cause its use in natural gas conventional combustion chambers to not give a complete combustion processes. Chacartegui et al. [42,43] investigated the effects produced by the use of syngas fuel on the performance and the environmental impact of CCPP. They focused on the difference of fuel characteristics and combustion products on main components, analyzing the value of Low Heating Values (LHV)s for various syngas compositions. They also analyzed the effect of syngas combustion, emissions and combustion chamber performance [44].

The heating value of syngas, (that is composed mainly of $\mathrm{CO}$ and $\mathrm{H}$ ), is lower than the LHV of natural gas. It implies a higher fuel supply to the combustor, increasing mass flow evolving through turbine. As described in [44], the use of syngas fuel and the derived combustion products affects the performance and the design of a CCPP plant. Syngas composition depends on the parameters involved in the gasification process [40,45-51]. Liang and Edward [45] highlighted the influence of the gasification process evolution on syngas properties. Due to the limited operational problems of the gas turbine elements, Kim et al. [50] deepened the study of energy performance limits in a combined cycle plant. In a CCPP plant, various elements like gas turbines are influenced from the adoption of syngas fuels from fossil or vegetal sources [44,51]. Some approaches are based on improving LHV by increasing $\mathrm{CH}_{4}$ presence in syngas trough methane enrichment procedures [52]. Recent studies are based on the natural gas/syngas use mixtures in order to obtain the optimal performance in terms of fuel efficiency and also flame velocity and propagation with a lower environmental impact in terms of pollutant emissions $[53,54]$. In this sense, numerical simulation represents today an important tool for the prevision of the effects in use of syngas [55-60].

This paper develops energy, environmental and economic analyses of a modern combined cycle plant with the objective to evaluate the potential benefits for a combined power plant running with alternative fuels in an area with a high biomass availability in order to reduce costs and global emissions. Different components and key parameters are examined. The CCPP under study is composed of two gas turbogenerators, two heat recovery steam generators and one steam turbogenerator as main equipment. Components of the CCPP plant are individually modelled, in order to be subsequently integrated in the whole system. Two power plant integrations are considered, with and without steam 
supply to a CHP facility. The optimal working conditions for the production of energy are evaluated and the impact of using syngas fuel in power plant performance is assessed.

Finally, with the aim to highlight the economic benefits of a technical-economic analysis of the plant feasibility, considering an operating plant profile is developed. Several scenarios are discussed, considering different factors of plant utilization, showing the potential interest of the proposed integration.

\section{Reference Power Plant and Models}

\subsection{Location of Geographical Area and Demand Model Definition}

Since 2005, an outstanding growth of energy demand has been experienced in India due to several reasons. One of the effects of the fast growth in Indian society has been the increase in electricity demand due to the fact that both industrial and urban areas have grown, and there is an increasing demand of new resources to sustain the economic development.

The potential for production of renewable syngas is strongly linked to the capacity for biomass gasification. The Ministry of New and Renewable Energy of the Government of India has recently reported that the actual availability of biomass in India is about 500 million metric tons per year, estimating a surplus biomass supply of 120-150 million metric tons per annum, referring rural and agricultural traces for a potential of about 18,000 MW [61]. Part of this biomass can be exploited as sustainable raw material for gasification producing alternative fuel for power production. It also can be used as alternative fuel to reduce natural gas supply dependence. In this way, the proper spatial location of biomass can improve the logistic network reducing fuel final costs [62-64]. As fossil fuels, biomass energy application will produce pollutant formations, but with adequate application of gasification and power technologies, they will have a lower impact than other fossil fuel sources and power conversion technologies. In this work is studied the installation of a CCPP plant in the city of Gurgaon located at $30 \mathrm{~km}$ from the city of Delhi (India) shown in Figure 1a. It is conceived as a Combined Heat and Power plant, where steam is provided to a refinery near the New Delhi area.

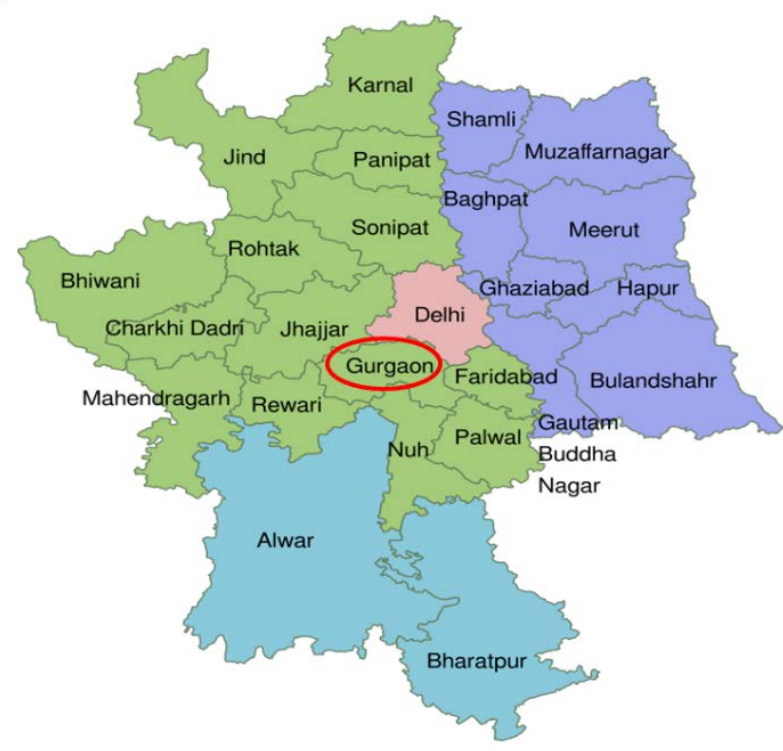

(a)

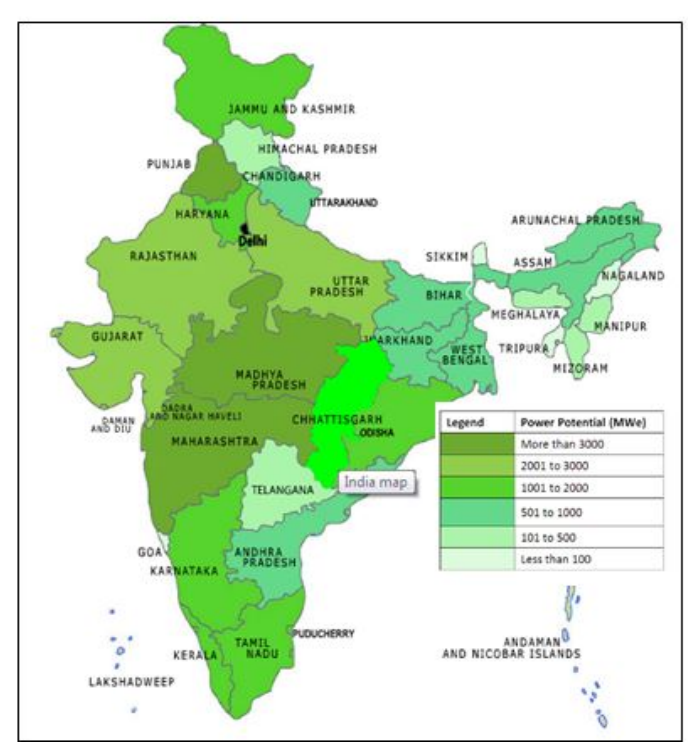

(b)

Figure 1. (a) Location of the combined cycle power plant [65]. (b) Biomass energy potential in India (in MWe) [66]. 
The position is strategic because the idea is to allow the energy production with low environmental impact near megacities as New Delhi, in a region with a higher availability of biomass (crop residues, plantation and manure biomass) and a higher biomass power potential [64]. In Figure 1b, the biomass energy potential in India in year 2016 is reported.

\subsection{Reference Layout}

The reference layout is a CHP combined cycle power plant that provides high pressure steam for processes in an adjacent refinery. It uses the steam to treat crude oil through a series of chemical processes that employ the steam generated. It should be possible to demand up to $80 \mathrm{t} / \mathrm{h}$ of steam at a pressure of 102 bars and at a temperature of $445^{\circ} \mathrm{C}$, which can be taken from the high pressure steam just before the entrance to the steam turbine. For the CHP application, the estimated steam demand evolution curve of the steam consumer company is illustrated in Figure 2.

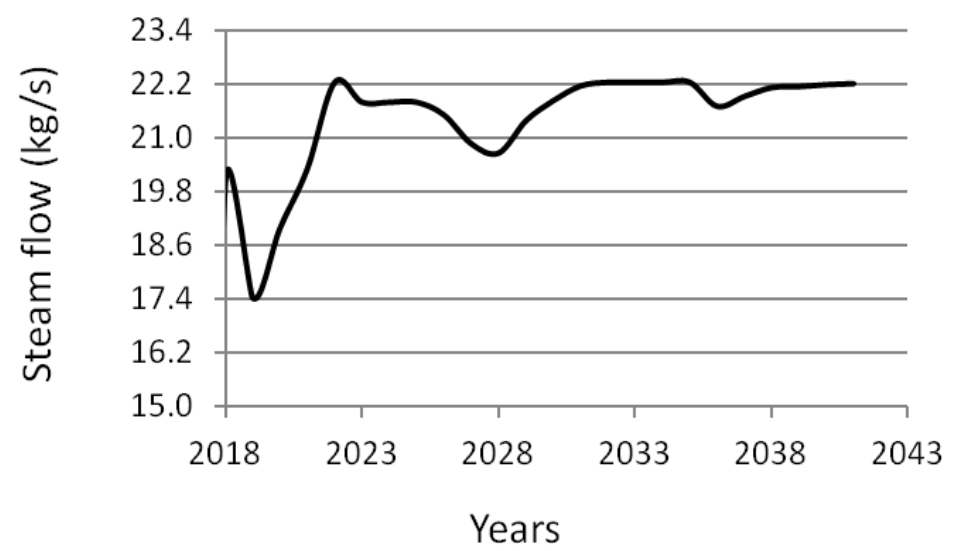

Figure 2. Demand curve of the steam consumer company.

The combined cycle rated power is $600 \mathrm{MW}$ with natural gas as main fuel. Figure 3 shows a detailed layout of the CCPP. It has a configuration 2-2-1: 2 gas turbogenerators/2 heat recovery steam generators (HRSG)/1 steam turbogenerator.

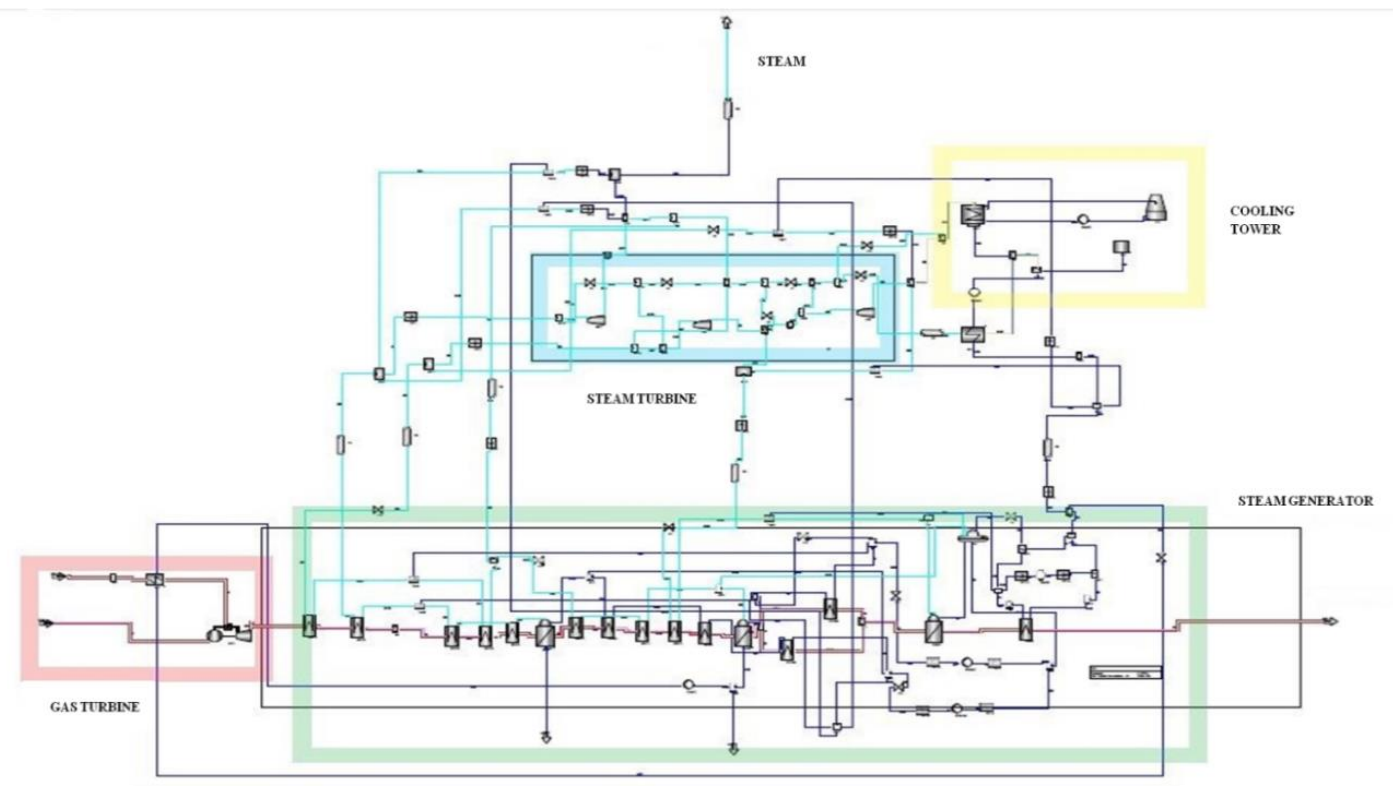

Figure 3. The main flowsheet of the model for the CCPP plant. 
Gas turbine exhaust gases generate steam at three pressures in the two heat recovery steam generators (HRSG). The boiler configuration also includes two additional evaporators, an intermediate pressure and a low pressure evaporator. Intermediate pressure steam can be mixed with the cold reheating before reheating and the low pressure steam to the turbine after mixing with the turbine intermediate pressure outlet. The boiler has two economizers in parallel to heat water at high and at intermediate pressure. At degasifier exhaust, the feedwater is distributed by means of two high and intermediate pressure pumps. A recirculation loop is provided to guarantee the conditions of the inlet water to the first economizer and before the degasifier as well as to control exhaust gases' stack temperature at $90^{\circ} \mathrm{C}$. Economizer water inlet temperature is around $55^{\circ} \mathrm{C}$. The generated steam expands in a three pressures and reheating steam turbine. Live steam enters at turbine at 160 bars and $500{ }^{\circ} \mathrm{C}$. Cooling towers are used as water refrigeration system because of the ambient conditions and water availability. Table 1 reports the main characteristics of the CCPP plant.

Table 1. Main features of the CCPP plant.

\begin{tabular}{ll}
\hline Location & Province of Gurgaon (India) $30 \mathrm{~km}$ from New Delhi. \\
Rated Power & $600 \mathrm{MW}$ \\
Combined cycle integration (GT/HR/ST) & $2 \times 2 \times 1$ with refrigeration tower \\
$\mathrm{CHP} /$ Steam demand & 102 bars, $445^{\circ} \mathrm{C}$. \\
Fuel & Gas natural/Biomass Syngas \\
Conditions considered in the study & New Delhi local ambient conditions \\
\hline
\end{tabular}

Gas turbogenerator exhaust gases are used to produce steam in the Heat Recovery Steam Generator (HRSG). Figure 4 illustrates layout for modelling the steam turbine (in Aspen Plus), with detail of main flows for the design of the turbine. As indicated in Figure 4, the S83 source is the main steam inlet from the steam generator. FPT1 gives cold stream conditions and the exit conditions will be those of the heated stream. The source S82 represents low pressure stream from the boiler, and S23 refers to turbine discharge. $\mathrm{S} 7$ collects the different sealing streams that will be unified before being sent to the gland steam condenser.

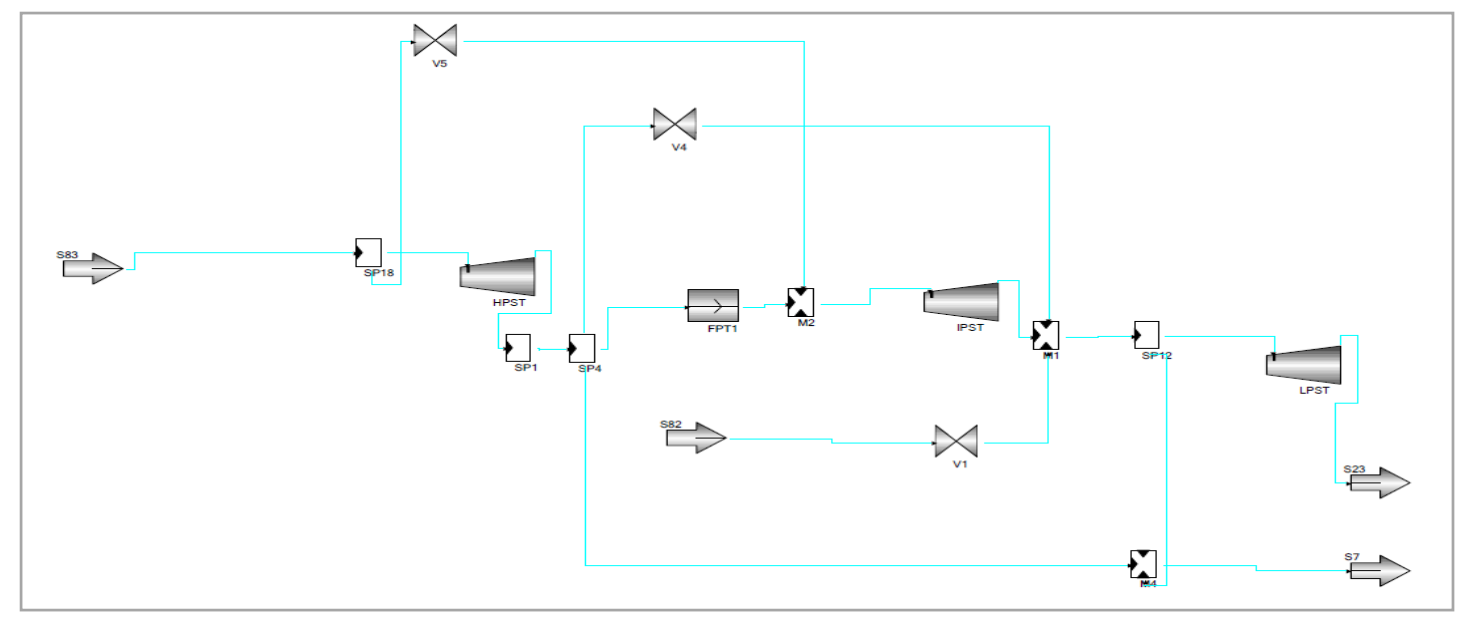

Figure 4. The flowsheet of steam turbine model.

In Figure 5 are presented the efficiency curve of the generator (a) and the efficiency curve of the high pressure section as function of the volumetric flow (b). 

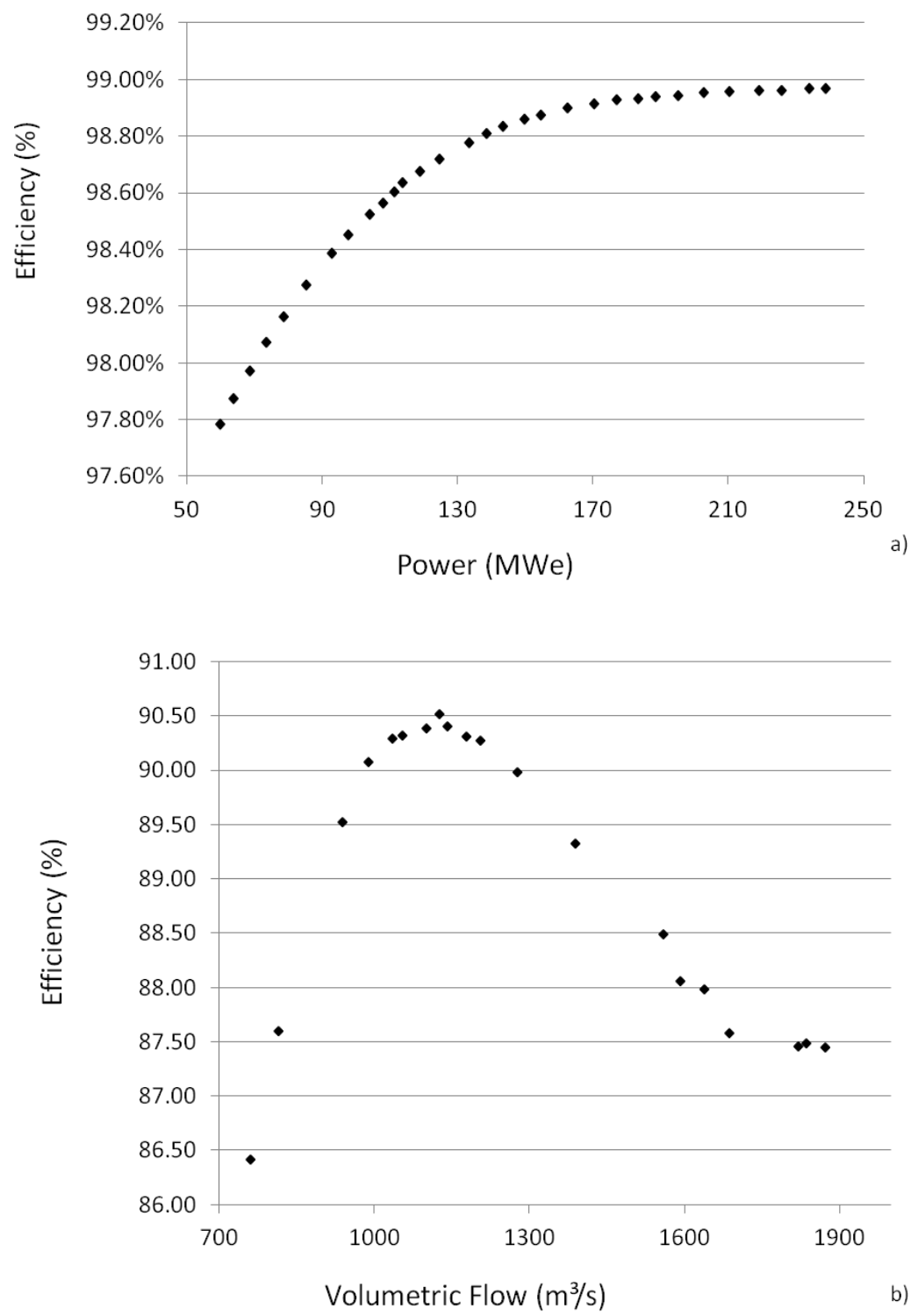

Figure 5. Input data: efficiency curve of the generator (a); Output data: efficiency curve of the high body in function of the volumetric flow (b).

Table 2 shows energy losses, expressed in energy fraction, in the different elements of the Heat Recovery Steam Generator (Figure 3) for different design conditions and loads: winter design, summer design, annual average and maximum extreme. 
Table 2. Fractional energy losses for Heat Recovery Steam Generator for different design conditions and loads: winter design, summer design, annual average and maximum extreme.

\begin{tabular}{|c|c|c|c|c|c|c|c|c|c|c|c|c|c|c|c|c|}
\hline $\begin{array}{c}\text { Fraction of Energy Loss } \\
\text { of Each Equipment }\end{array}$ & SPHT2 & SPHT3 & SPHT8 & SPHT5 & SPHT4 & EVAP3 & SPHT6 & ECON3 & SPHT1 & SPHT9 & ECON7 & EVAP2 & ECON5 & ECON6 & EVAP1 & ECON1 \\
\hline Summer design $100 \%$ & 0.001 & 0.001 & 0.001 & 0.001 & 0.001 & 0.001 & 0.001 & 0.001 & 0.001 & 0.001 & 0.001 & 0.001 & 0.001 & 0.001 & 0.001 & 0.03 \\
\hline Summer design $75 \%$ & 0.08 & 0.08 & 0.08 & 0.08 & 0.08 & 0.001 & 0.08 & 0.08 & 0.08 & 0.08 & 0.08 & 0.001 & 0.001 & 0.001 & 0.001 & 0.12 \\
\hline Summer design $\mathbf{5 0} \%$ & 0.1 & 0.1 & 0.1 & 0.1 & 0.1 & 0.001 & 0.1 & 0.1 & 0.1 & 0.1 & 0.1 & 0.001 & 0.001 & 0.001 & 0.001 & 0.12 \\
\hline Annual average $100 \%$ & 0.001 & 0.001 & 0.001 & 0.001 & 0.001 & 0.01 & 0.001 & 0.08 & 0.001 & 0.001 & 0.08 & 0.001 & 0.001 & 0.001 & 0.03 & 0.04 \\
\hline Annual average $75 \%$ & 0.08 & 0.08 & 0.08 & 0.08 & 0.08 & 0.01 & 0.08 & 0.08 & 0.08 & 0.08 & 0.08 & 0.001 & 0.001 & 0.001 & 0.001 & 0.12 \\
\hline Annual average $50 \%$ & 0.1 & 0.1 & 0.1 & 0.1 & 0.1 & 0.001 & 0.1 & 0.1 & 0.1 & 0.1 & 0.1 & 0.001 & 0.001 & 0.001 & 0.001 & 0.12 \\
\hline Winter design $\mathbf{1 0 0} \%$ & 0.001 & 0.001 & 0.001 & 0.001 & 0.001 & 0.01 & 0.001 & 0.08 & 0.001 & 0.001 & 0.08 & 0.001 & 0.001 & 0.001 & 0.03 & 0.04 \\
\hline Winter design $75 \%$ & 0.08 & 0.08 & 0.08 & 0.08 & 0.08 & 0.01 & 0.08 & 0.08 & 0.08 & 0.08 & 0.08 & 0.001 & 0.001 & 0.001 & 0.001 & 0.12 \\
\hline Winter design $\mathbf{5 0} \%$ & 0.1 & 0.1 & 0.1 & 0.1 & 0.1 & 0.001 & 0.1 & 0.1 & 0.1 & 0.1 & 0.1 & 0.001 & 0.001 & 0.001 & 0.001 & 0.12 \\
\hline Winter minimum $100 \%$ & 0.001 & 0.001 & 0.001 & 0.001 & 0.001 & 0.01 & 0.001 & 0.08 & 0.001 & 0.01 & 0.08 & 0.001 & 0.001 & 0.001 & 0.03 & 0.04 \\
\hline Winter minimum 75\% & 0.08 & 0.08 & 0.08 & 0.08 & 0.08 & 0.01 & 0.08 & 0.08 & 0.08 & 0.08 & 0.08 & 0.001 & 0.001 & 0.001 & 0.001 & 0.12 \\
\hline Winter minimum $50 \%$ & 0.1 & 0.1 & 0.1 & 0.1 & 0.1 & 0.01 & 0.1 & 0.1 & 0.1 & 0.1 & 0.1 & 0.001 & 0.001 & 0.001 & 0.001 & 0.12 \\
\hline Maximum extreme $100 \%$ & 0.001 & 0.001 & 0.001 & 0.001 & 0.001 & 0.001 & 0.001 & 0.001 & 0.001 & 0.001 & 0.001 & 0.04 & 0.001 & 0.001 & 0.001 & 0.03 \\
\hline Maximum extreme $75 \%$ & 0.08 & 0.08 & 0.08 & 0.08 & 0.08 & 0.001 & 0.08 & 0.08 & 0.08 & 0.08 & 0.08 & 0.001 & 0.001 & 0.001 & 0.001 & 0.12 \\
\hline Maximum extreme $50 \%$ & 0.1 & 0.1 & 0.1 & 0.1 & 0.1 & 0.001 & 0.1 & 0.1 & 0.1 & 0.1 & 0.1 & 0.001 & 0.001 & 0.001 & 0.001 & 0.12 \\
\hline
\end{tabular}


Figure 6 shows the Temperature Heat Transfer diagram, TQ diagram of the Heat Recovery Steam Generator, HRSG, under design conditions. Red line represents the evolution of the exhaust gases through the HRSG. Blue line represents the steam and water in the different elements.

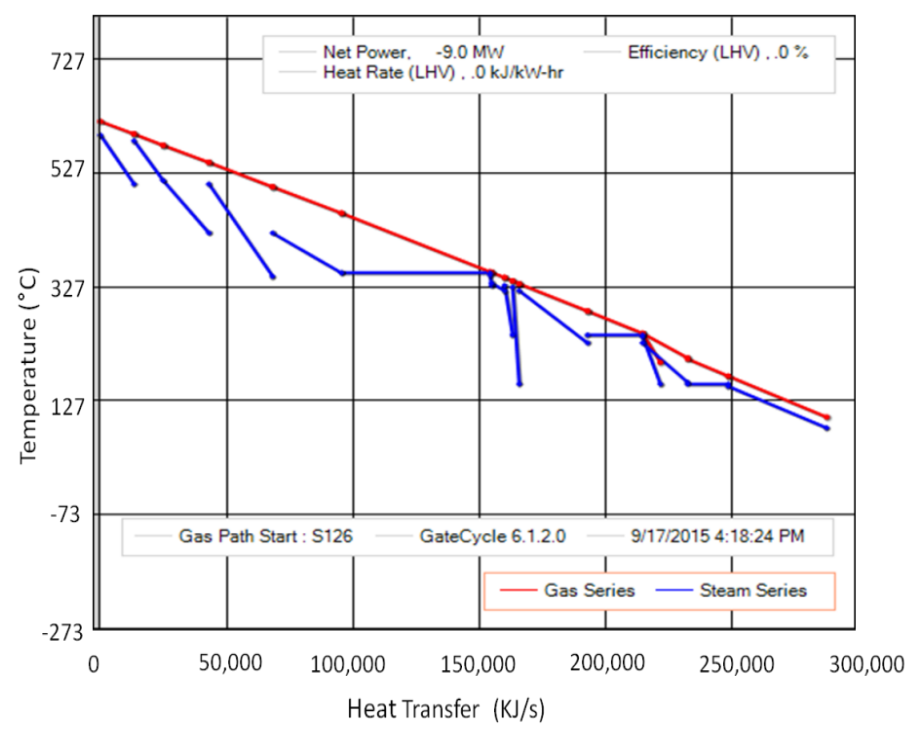

Figure 6. TQ diagram of the boiler.

\section{Model Definition}

\subsection{Operational Curves}

In order to maximize CCPP performance, four different gas turbine models were evaluated. They were selected because of their suitability to the global system requirements. The four gas turbines considered are GE 7FA.05 (TG1), Siemens SGT6-8000H (TG2), GE7FA.04 (TG3) and GEM9001E (TG4).

To estimate power cycle performance, the curves of each turbine are implemented in the numerical simulation. The same configurations for the generator and steam turbine have been kept in the analysis of the different gas turbines. In the first analysis, natural gas has been considered as fuel. Natural gas composition is given in Table 3.

Table 3. Natural gas composition.

\begin{tabular}{ccc}
\hline & Units & Natural Gas \\
\hline Methane & $\% \mathrm{~mol}$ & $84.777 \%$ \\
Ethane & $\% \mathrm{~mol}$ & $6.338 \%$ \\
Propane & $\% \mathrm{~mol}$ & $0.248 \%$ \\
Nitrogen & $\% \mathrm{~mol}$ & $8.637 \%$ \\
LHV & $\mathrm{kJ} / \mathrm{kg}$ & $43,034.16$ \\
$\mathrm{HCV}$ & $\mathrm{kJ} / \mathrm{kg}$ & $47,701.28$ \\
ratio H/C & - & 3.861 \\
\hline
\end{tabular}

Additional analyses are performed considering the effect of using alternative syngas fuels. They are obtained through a gasification process that consists of a partial oxidation of a solid fuel. The characteristics of the syngas fuel compositions and features used in this work are given in Table 4 . 
Table 4. Composition of the syngases considered.

\begin{tabular}{cccccc}
\hline & & Syngas 1 [67] & Syngas 2 [68] & Syngas 3 [69] & Syngas 4 [70] \\
\hline $\mathrm{CH}_{4}$ & $\%$ & $1.00 \%$ & $0.37 \%$ & $0.00 \%$ & $7.10 \%$ \\
$\mathrm{~N}_{2}$ & $\%$ & $6.55 \%$ & $0.00 \%$ & $12.47 \%$ & $0.00 \%$ \\
$\mathrm{H}_{2}$ & $\%$ & $35.79 \%$ & $49.66 \%$ & $22.09 \%$ & $39.40 \%$ \\
$\mathrm{CO}$ & $\%$ & $34.84 \%$ & $48.68 \%$ & $60.52 \%$ & $33.42 \%$ \\
$\mathrm{CO}_{2}$ & $\%$ & $21.82 \%$ & $1.29 \%$ & $3.88 \%$ & $19.59 \%$ \\
$\mathrm{Ar}$ & $\%$ & $0.00 \%$ & $0.00 \%$ & $1.04 \%$ & $0.00 \%$ \\
$\mathrm{O}_{2}$ & $\%$ & $0.00 \%$ & $0.00 \%$ & $0.00 \%$ & $0.49 \%$ \\
$\mathrm{H}_{2} \mathrm{O}$ & $\%$ & $0.00 \%$ & $0.00 \%$ & $0.00 \%$ & $0.00 \%$ \\
$\mathrm{LHV}$ & $\mathrm{kJ} / \mathrm{kg}\left(25^{\circ} \mathrm{C}\right)$ & 8756 & 17,102 & 9771 & 12,306 \\
\hline
\end{tabular}

The effects of the different fuels on $\mathrm{CO}_{2}$ emission are analyzed in the next section.

\subsection{System Optimization Discussion}

The cycle efficiency, $\eta$, is defined as the ratio between the net power, $\dot{W} n e t$ between, and the fuel consumption, indicated as $C_{t o t}$ :

$$
\eta=\frac{\dot{W}_{n e t}}{C_{t o t}}
$$

and the Heat Rate:

$$
\mathrm{HR}=\frac{C_{t o t}}{\dot{W}_{\text {net }}} * 3600
$$

In Table 5 are reported the estimated net power values for the steam turbine, considering the four different gas turbines at full load operation working at different ambient temperatures.

Table 5. Steam Turbine Net Power (MW) for different gas turbines model at full load operation.

\begin{tabular}{|c|c|c|c|c|c|}
\hline & Net Power ST (MW) & & & & \\
\hline & $100 \%$ Charge TG & $1 G 1$ & $1 G 2$ & $1 \mathrm{G} 3$ & $1 G 4$ \\
\hline \multirow{4}{*}{$\begin{array}{c}\text { Ambient Temperature } \\
\left({ }^{\circ} \mathrm{C}\right)\end{array}$} & $11.5^{\circ} \mathrm{C}$ & 212.12 & 244.43 & 170.07 & 113.27 \\
\hline & $15.7^{\circ} \mathrm{C}$ & 211.74 & 242.47 & 170.76 & 113.28 \\
\hline & $26.5^{\circ} \mathrm{C}$ & 205.96 & 236.78 & 168.06 & 113.40 \\
\hline & $38.4^{\circ} \mathrm{C}$ & 202.04 & 222.48 & 159.36 & 108.24 \\
\hline
\end{tabular}
GE 7FA.05 (TG1), Siemens SGT6-8000H (TG2), GE7FA.04 (TG3), GEM9001E (TG4).

Cycle net power, efficiency and Heat Rate as function of temperature are presented in Figure 7. 

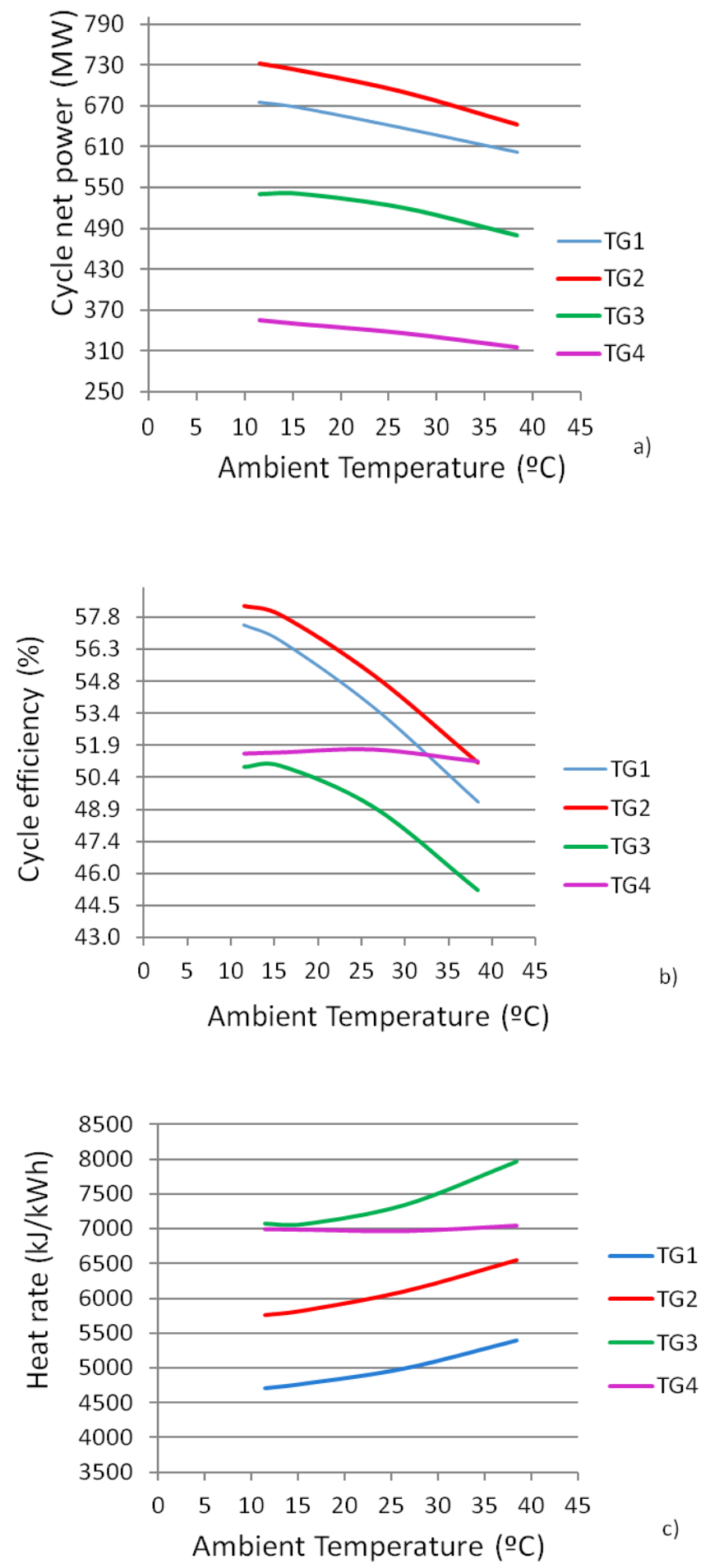

Figure 7. Analysis of the effect of gas turbine selection in Combined Cycle (a) Net power; (b) Cycle efficiency; (c) Heat rate. GE 7FA.05 (TG1), Siemens SGT6-8000H (TG2), GE7FA.04 (TG3), GEM9001E (TG4).

Figure 7a-c show main parameters of the CCPP for the four gas turbines selected, at full load operation conditions and fuelled with natural gas. As ambient temperature increases, the power provided by the gas turbine and the steam turbine drop. It is due to the effect on air density, the decrease in the steam generated in the HRSG and the drop in turbine expansion. Comparing the results obtained for the gas turbines under analysis, Siemens SGT6-8000H gas turbine combined cycle 
achieves a higher power, with a higher exhaust gas mass flow and a higher steam generation. Siemens SGT6-8000H (TG2) reaches the highest value in power: an additional share of the $8 \%$ compared to the GE 7FA.05 (TG1) and up to $17 \%$ in respect to GE7FA.04 (TG3).

Table 6 reports net power of the cycle considering the four different gas turbines at full load operations, at different ambient temperatures.

Table 6. Net Power of the Cycle for the different gas turbines at full load operation. GE 7FA.05 (TG1), Siemens SGT6-8000H (TG2), GE7FA.04 (TG3), GEM9001E (TG4).

\begin{tabular}{|c|c|c|c|c|c|}
\hline & Cycle Net Power (MW) & \multirow{2}{*}{ TG1 } & \multirow{2}{*}{ TG2 } & \multirow{2}{*}{ TG3 } & \multirow{2}{*}{ TG4 } \\
\hline & $100 \%$ Charge TG & & & & \\
\hline \multirow{4}{*}{$\begin{array}{l}\text { Ambient Temperature } \\
\qquad\left({ }^{\circ} \mathrm{C}\right)\end{array}$} & $11.5^{\circ} \mathrm{C}$ & 675.990 & 731.808 & 539.939 & 354.854 \\
\hline & $15.7^{\circ} \mathrm{C}$ & 667.889 & 721.735 & 540.418 & 349.233 \\
\hline & $26.5^{\circ} \mathrm{C}$ & 637.402 & 690.083 & 520.028 & 335.964 \\
\hline & $38.4^{\circ} \mathrm{C}$ & 601.325 & 642.004 & 479.576 & 315.271 \\
\hline
\end{tabular}

Cycle efficiency is evaluated through gross power, flow composition, exhaust gas temperature, fuel features and parasitic power consumption of auxiliaries. Cycle efficiency values at full load operation and different ambient temperature are given in Table 7.

Table 7. Cycle efficiency for different gas turbines at full load operation. GE 7FA.05 (TG1), Siemens SGT6-8000H (TG2), GE7FA.04 (TG3), GEM9001E (TG4).

\begin{tabular}{|c|c|c|c|c|c|}
\hline & Cycle Efficiency (\%) & TC1 & TC? & TC? & TCA \\
\hline & $100 \%$ Charge TG & 101 & 102 & 100 & 104 \\
\hline \multirow{4}{*}{$\begin{array}{c}\text { Ambient Temperature } \\
\left({ }^{\circ} \mathrm{C}\right)\end{array}$} & $11.5^{\circ} \mathrm{C}$ & 57.43 & 58.74 & 50.90 & 51.52 \\
\hline & $15.7^{\circ} \mathrm{C}$ & 56.71 & 59.26 & 50.94 & 51.57 \\
\hline & $26.5^{\circ} \mathrm{C}$ & 53.59 & 56.44 & 49.01 & 51.70 \\
\hline & $38.4{ }^{\circ} \mathrm{C}$ & 49.24 & 52.41 & 45.20 & 51.15 \\
\hline
\end{tabular}

Figure $7 \mathrm{~b}, \mathrm{c}$ show cycle efficiency and heat rate trends obtained from the simulations for the four gas turbines. Siemens SGT6-8000H (TG2) has an efficiency 18\% and 35\% higher than GE 7FA.05 (TG1) and GE7FA.04 (TG3) respectively. It is also possible to observe how GEM9001E (TG4) is the turbine in which ambient temperature changes have a minor effect on the efficiency.

Additional to these analyses, other aspects must be taken into account, comparing those with a higher efficiency, GE 7FA.05 (TG1) and Siemens SGT6-8000H (TG2). The GE turbine has an annular tube combustion chamber and Siemens gas turbine has an annular design, with a probable less uniform fuel/air mixture. Besides, it has a dry, low NOx system with a lower temperature with reduced NOx emissions with full load operation.

\section{Effect of Fuel Operation}

Based on a criterion of lower emissions, in this section, the effect of using alternative fuels is analyzed. In Figure 8 is presented the degradation curve of the gas turbine considered in this section. 


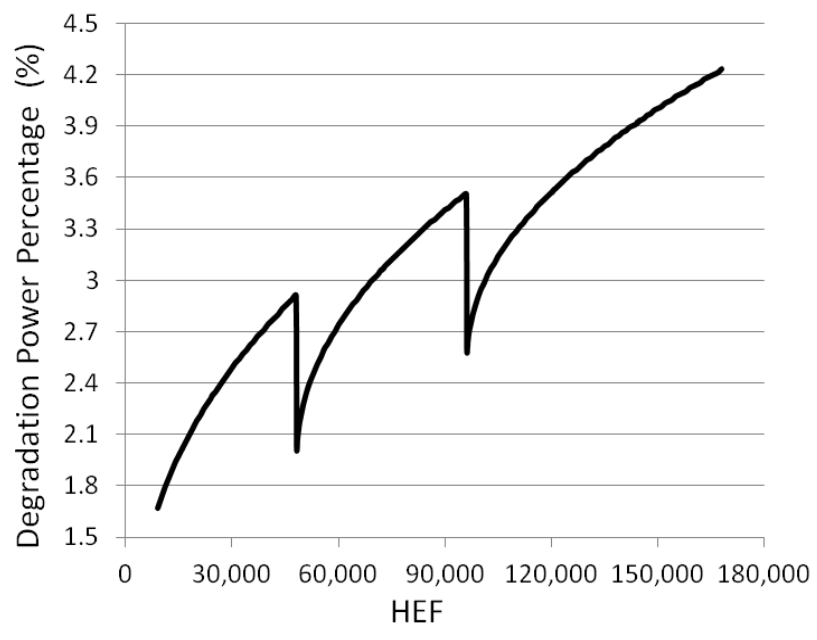

Figure 8. Turbine gas degradation curve.

Table 8 shows net power values for the different fuels considered at different ambient temperatures. These values are obtained considering full load operation capacity of the gas turbine for the considered syngases.

Table 8. Combined Cycle net power fuelled with different syngases.

\begin{tabular}{ccccccc}
\hline & Cycle Net Power (MW) & Natural Gas & Syngas 1 & Syngas 2 & Syngas 3 & Syngas 4 \\
\hline Ambient & 11.5 & 553.776 & 615.143 & 570.883 & 576.336 & 592.542 \\
Temperature & 15.7 & 543.646 & 603.873 & 560.440 & 565.782 & 581.728 \\
$\left({ }^{\circ} \mathrm{C}\right)$ & 26.5 & 519.660 & 577.200 & 535.701 & 540.718 & 556.025 \\
& 38.4 & 485.899 & 539.691 & 500.842 & 505.528 & 519.953 \\
\hline
\end{tabular}

Figure 9 shows the effect of fuel on the net power of the cycle. Using syngas GS1, an additional $11 \%$ net power can be obtained, considering full load capacity of the gas turbine for all the fuels and variation range. Depending on the ambient temperature for all the fuels considered, the heat rate evolution gives an idea of the power of the fuel consumed per unit of energy produced. Figure $9 \mathrm{~b}$ shows the efficiency and Figure 9c shows the Heat Rate. The results show how using syngas fuel Heat Rate can be decreased by 3\% with respect to natural gas. Table 9 shows the Heat Rate values at different ambient temperatures for the different fuels. 

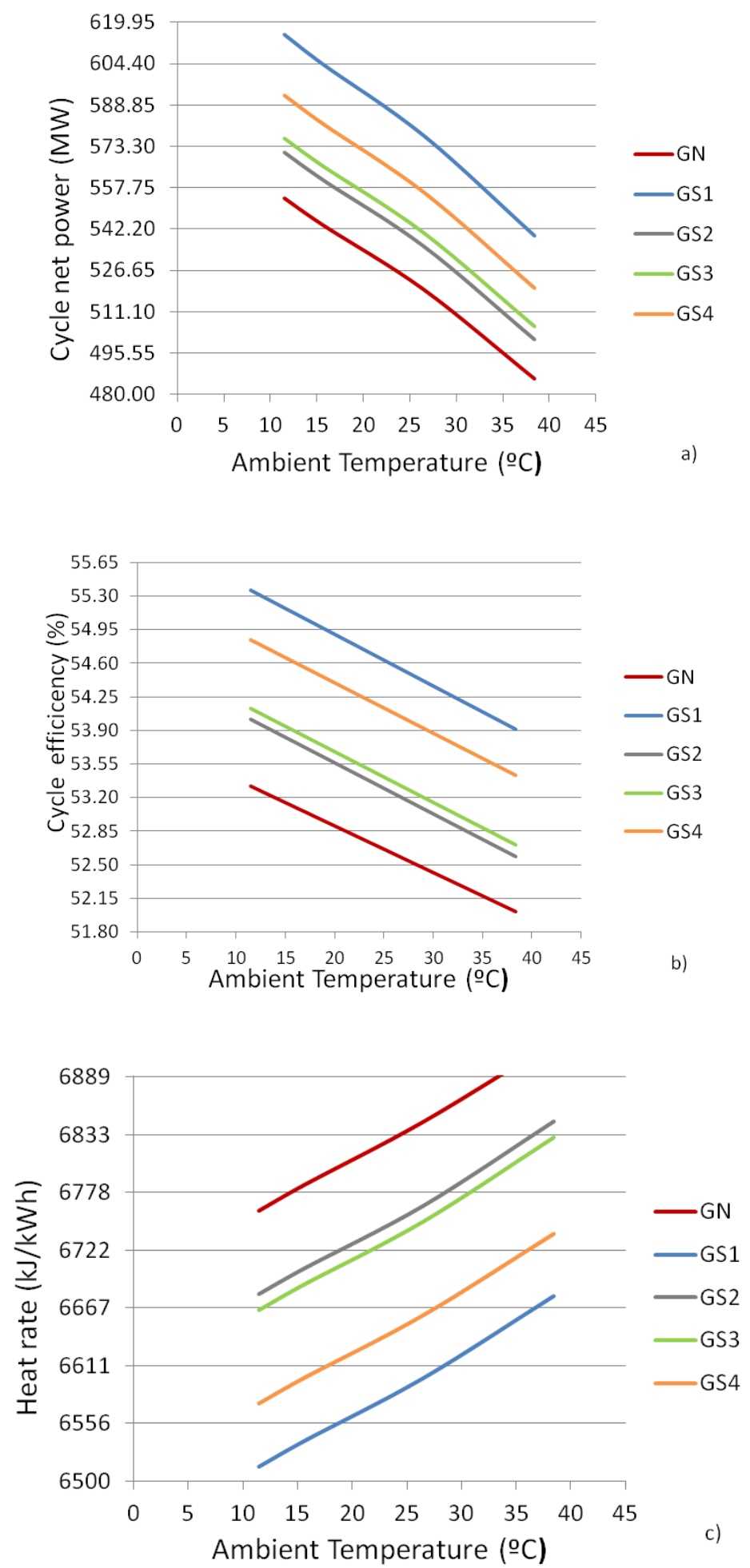

Figure 9. Analysis of fuel in CCPP performance: (a) Net Power; (b) Cycle efficiency; (c) Heat rate. 
Table 9. Cycle heat rate for the different syngases considered.

\begin{tabular}{ccccccc}
\hline & Cycle Heat Rate (kJ/kWh) & Natural Gas & Syngas 1 & Syngas 2 & Syngas 3 & Syngas 4 \\
\hline Ambient & 11.5 & 6864.0 & 6622.7 & 6790.1 & 6774.0 & 6684.0 \\
Temperature & 15.7 & 6856.6 & 6616.1 & 6782.8 & 6766.6 & 6676.6 \\
$\left({ }^{\circ} \mathrm{C}\right)$ & 26.5 & 6837.5 & 6599.0 & 6764.3 & 6749.3 & 6659.5 \\
& 38.4 & 6918.7 & 6677.7 & 6845.7 & 6829.9 & 6737.7 \\
\hline
\end{tabular}

Table 10 gives CCPP efficiency operating with the different fuels:

Table 10. Cycle efficiency for the different fuels considered.

\begin{tabular}{ccccccc}
\hline & Cycle Efficiency (\%) & Natural Gas & Syngas 1 & Syngas 2 & Syngas 3 & Syngas 4 \\
\hline Ambient & 11.5 & 52.446 & 54.356 & 53.017 & 53.143 & 53.858 \\
Temperature & 15.7 & 52.502 & 54.410 & 53.074 & 53.200 & 53.865 \\
$\left({ }^{\circ} \mathrm{C}\right)$ & 26.5 & 52.649 & 54.552 & 53.219 & 53.337 & 54.056 \\
& 38.4 & 52.031 & 53.909 & 52.586 & 52.707 & 53.429 \\
\hline
\end{tabular}

Figure 10 shows the exhaust $\mathrm{CO}_{2}$ percentage for the analyzed fuels.

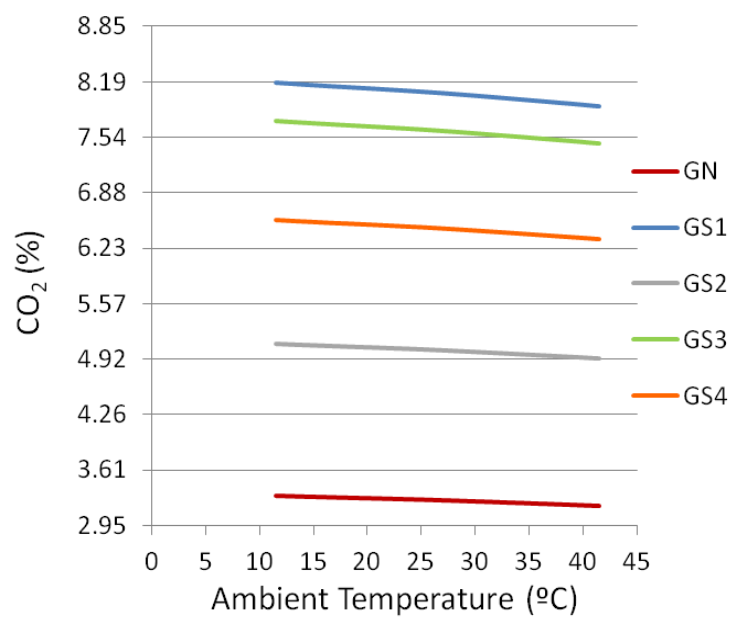

Figure 10. Exhaust $\mathrm{CO}_{2}$ percentage for the different fuels considered.

The proper fuel mixture between natural gas and syngas can generate benefits in terms of lower environmental impact than natural gas, and at the same time, maintain a good combustion performance.

In previous work [44], authors here have proposed three different cases of operative conditions for the CCPP plant analyzed, changing the percentages of fuel supply between traditional natural gas and syngas. In Table 11, three mixtures are considered for the analysis, based on syngas 2 (GS2), with a low $\mathrm{CO}_{2}$ value and good efficiency values.

Table 11. Different cases proposed with different mixture percentage of natural gas and syngas.

\begin{tabular}{ccc}
\hline & Natural Gas (\%) & Syngas GS2 (\%) \\
\hline Case 1 & 90 & 10 \\
Case 2 & 80 & 20 \\
Case 3 & 70 & 30 \\
\hline
\end{tabular}

\section{Combined Cycle Plant Correction Curves}

To analyze into detail the plant behavior, different analyses are performed for different ambient conditions and for the two different considered operating conditions: without and with steam export. 
The gas turbine GEM9001E (TG4) is used for the analysis. Table 12 shows the estimated outputs of the plant for both cases.

Table 12. Power and heat rate values without and with steam export at full load operation (100\% load).

\begin{tabular}{cc}
\hline -REFERENCE VALUES AS POWER PLANT (without Steam Export) & \\
\hline Net Power (MW) & 587.68 \\
Net Heat rate (KJ/KWh) & 684.13 \\
\hline -REFERENCE VALUES AS CHP (with Steam Export) & 576.68 \\
\hline Net Power (MW) & 6970.5 \\
\hline Net Heat rate (KJ/KWh)
\end{tabular}

Figure 11 shows the correction curves of the combined cycle as function of temperature in both configurations, as CHP with steam extraction (red line in the graph) and as standalone power plant (black line).
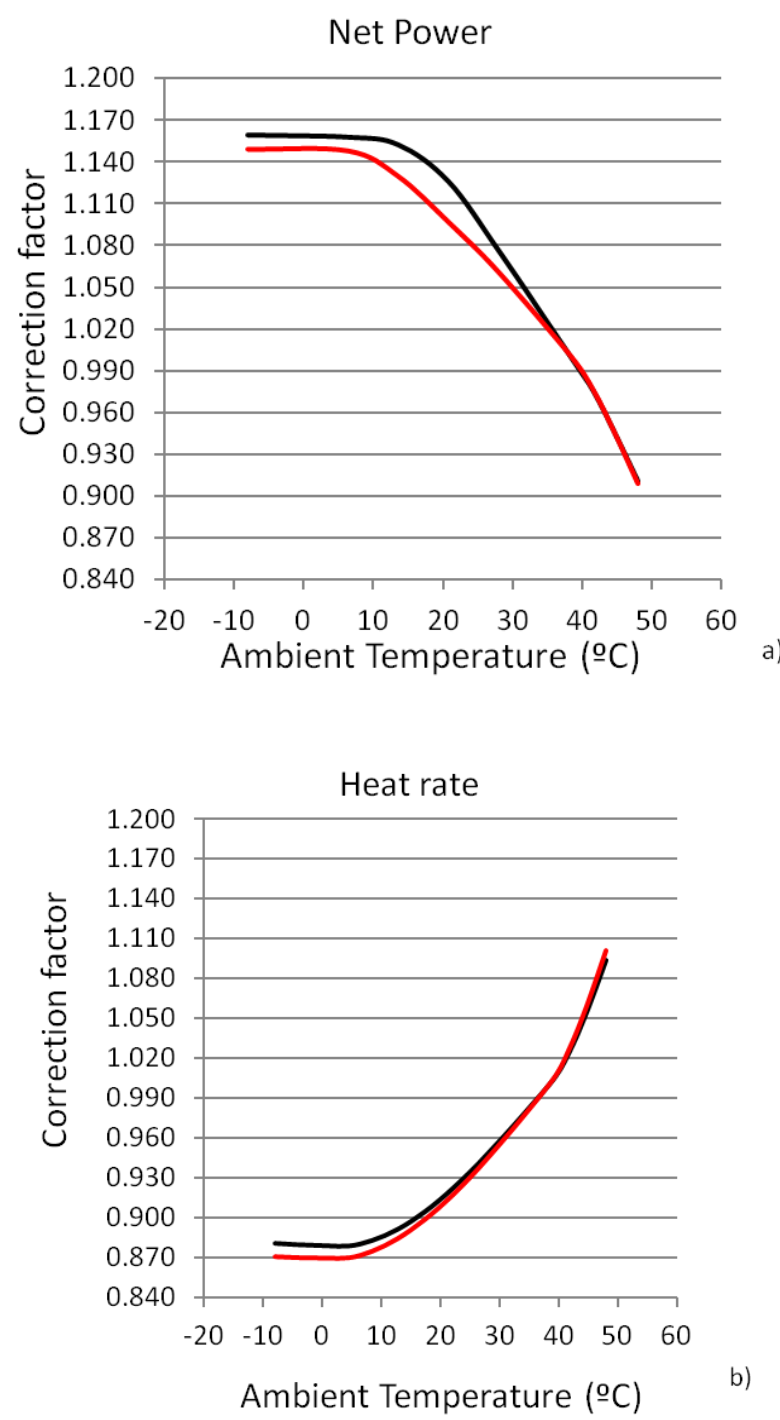

Figure 11. Effect of ambient temperature on combined cycle performance. Correction factors as function of ambient temperature for (a) power and (b) heat rate, with (red line) and without (black line) steam export. 
Figure 11 shows the effect of steam extraction for $\mathrm{CHP}$ on the global curves correction factors. It shows that a temperature drop of $10{ }^{\circ} \mathrm{C}$ implies a power drop of $4.4 \%$ in the standalone power plant operation mode; meanwhile, that in the CHP operation mode power, decrease is $3.2 \%$. This is due to the different reference in both cases. Figure 11 shows how an increase in the temperature clearly penalizes combined cycle net power, i.e., an ambient temperature rise of $9.4^{\circ} \mathrm{C}$ reduces in $9 \%$ the net power. It can be observed an opposite trend for the heat rate (Figure 11b). For the same increase of $10{ }^{\circ} \mathrm{C}$, the heat rate grows by $9 \%$ with respect to the reference value. The comparison between the two case results confirms that at low temperatures, the increase in power acquired by not cogenerating is more pronounced. As the ambient temperature increases, this effect becomes less important, and for temperatures around $45^{\circ} \mathrm{C}$, the previous trend is reversed since the power delivered is severely penalized by the maximum extreme conditions.

In Figure 12 are shown the effect of combined cycle parameters as function of relative humidity at different ambient temperatures of $11.5^{\circ} \mathrm{C}, 17.5^{\circ} \mathrm{C}, 26.5^{\circ} \mathrm{C}$ and $38.4^{\circ} \mathrm{C}$ without (Figure 12a,b) and with steam export (Figure 12c,d).
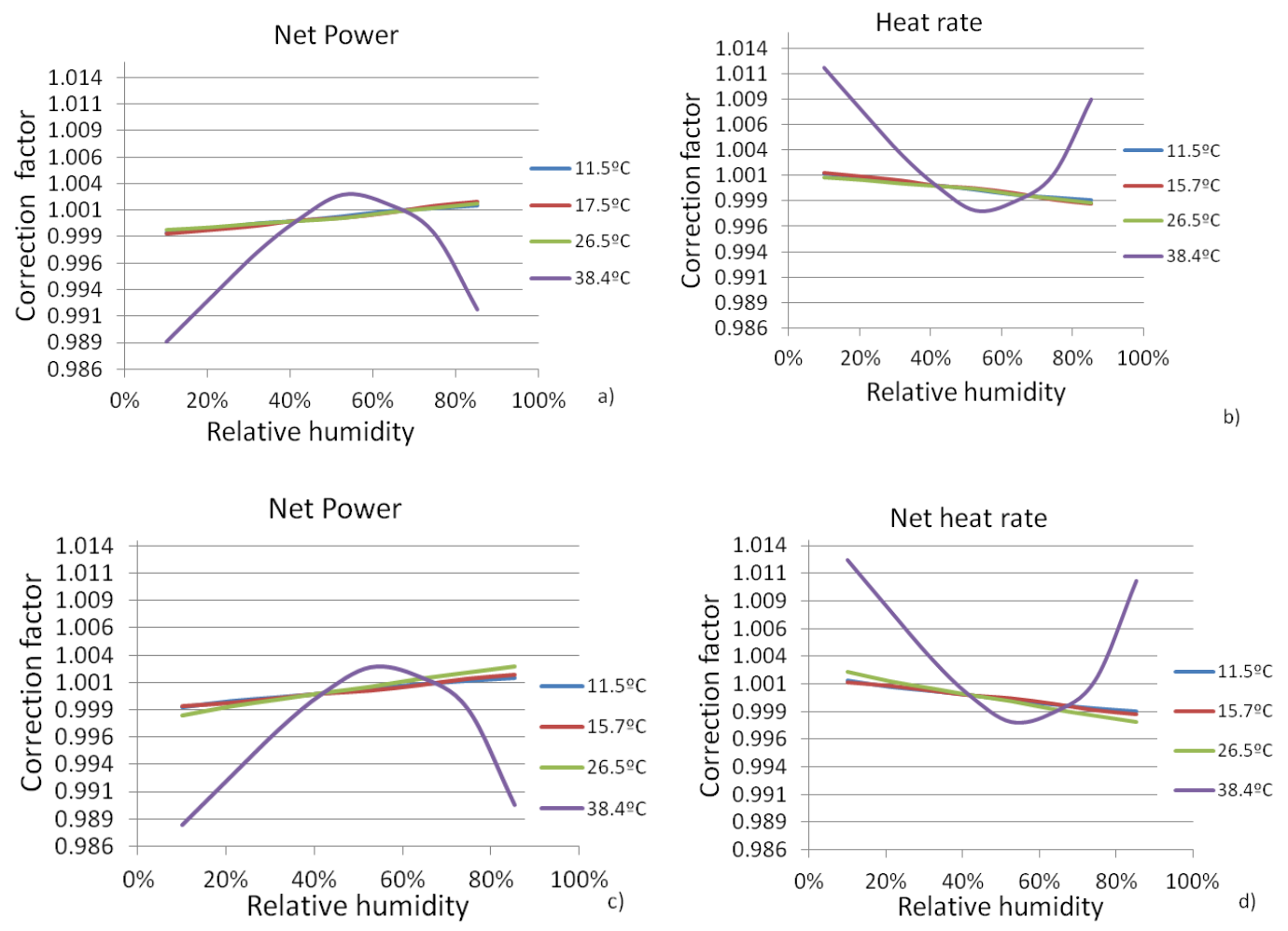

Figure 12. Effect of relative humidity on combined cycle performance at different ambient temperatures. Power and Heat Rate correction factors without steam export (a,b); and with steam export (c,d).

The results obtained show that for a relative humidity lower than the reference, the power decreases and heat rate increases; on the other hand, by increasing relative humidity to values higher than the reference, the inverse trend is observed. It is clear that for high temperatures $\left(38.4^{\circ} \mathrm{C}\right)$, the fluctuation of the corresponding parameter implies a greater variation. Figure 13 shows the effect of ambient pressure on combined cycle performance for both configurations. 

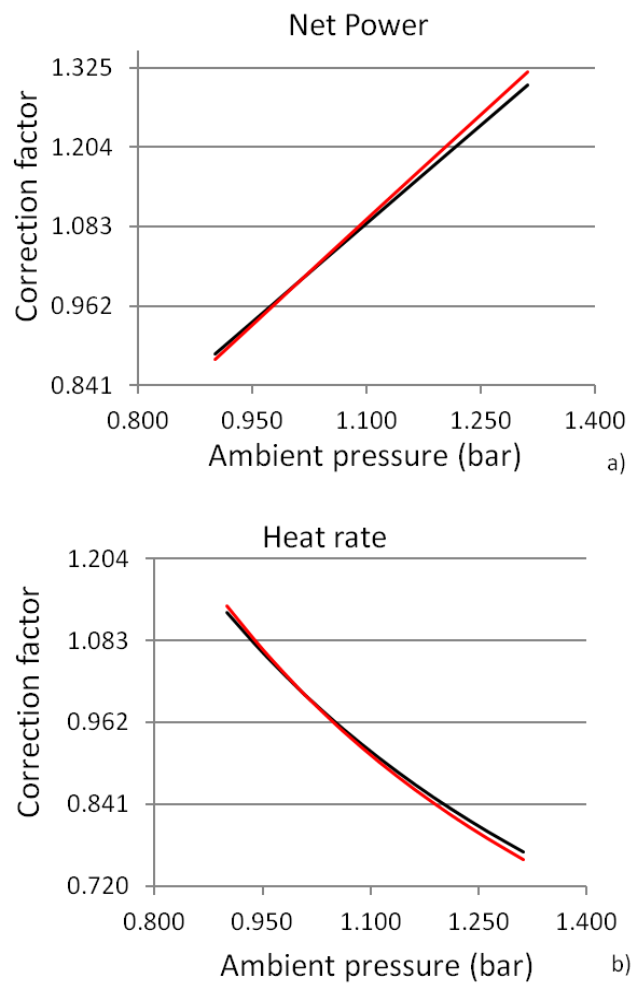

Figure 13. Effect of ambient pressure on combined cycle performance. Correction factors with (red line) and without (black line) steam export for (a) power; (b) heat rate.

Figure 13 shows how power is increased with higher ambient pressure. This effect is greater with CHP operation, when exporting steam. Power variations of $11 \%$ can be obtained depending on ambient pressure.

Figure 14 shows the effect of fuel's Low Heat Value (LHV) on combined cycle performance for the two operative conditions proposed. This situation collects the effect of fuel composition variation.
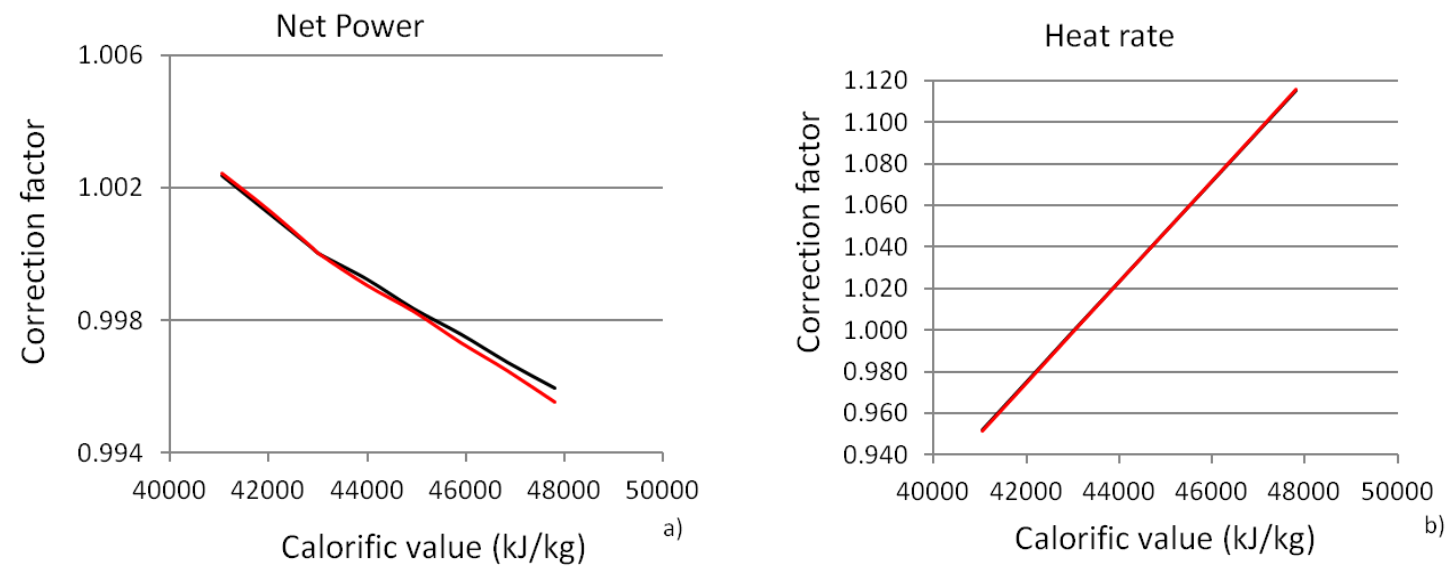

Figure 14. Effect of Fuel Low Heat value on combined cycle performance. Correction factors with (red) and without (black) steam export: (a) power; (b) heat rate.

In regard to the combined cycle power trend with fuel LHV (Figure 14a), results show that for fuels with LHV lower than the reference, there are not significant variations in power factors. With higher LHV values, in CHP configuration, steam export condition penalizes generation by $2 \%$. Heat rate is not affected by the variation and it is practically an independent condition, as highlighted in Figure 14b. 
The relative difference of the factors of both conditions represents a discrepancy of $0.05 \%$ in the most unfavorable case.

Finally, in Figure 15a,b, the cycle parameters have variations when the power factor of the gas turbine is changed. This has a direct consequence on the power delivered by the gas turbine. The higher the power factor, the greater the active power generated and the lower the reactive power.
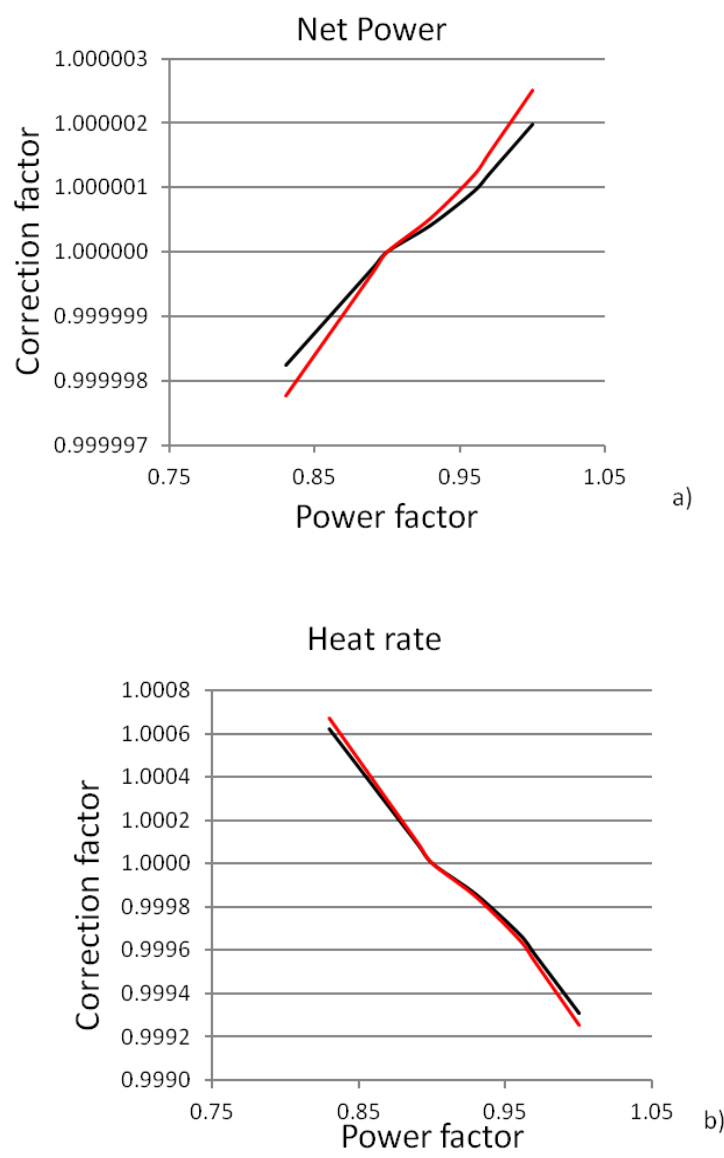

Figure 15. Corrective factors of net power (a) and heat rate (b) for different power of gas turbine with (red line) and without (black line) steam export.

\section{Economic Analysis}

For this study, we have assumed that initial investment is divided in $55 \%$ provided by the owner and the $45 \%$ will be provided by a loan from the World Bank, with a nominal interest rate of $10 \%$ without commission, with amortizations and annual liquidations. The construction period of the ССРP can be long and it can go through several years depending on the geographical and commercial circumstances that can be applied to the project. In our case, we have assumed that the start-up will be two years after the start of the civil works. In this way, we have considered those two additional years against the return of the investment in making the investment profitable. We based our analysis on an initial investment cost of $€ 365 \mathrm{M}$ that is broken down according to a percentage of the total as considered in Table 13: 
Table 13. Capital Expenditure (Capex).

\begin{tabular}{ccc}
\hline Initial Investment & Weight & Absolute Value (M€) \\
\hline Gas turbines (assembly and supply) & $28.7 \%$ & 104.64 \\
Boilers (assembly and supply) & $14.0 \%$ & 50.94 \\
Steam turbines (assembly and supply) & $11.0 \%$ & 40.01 \\
Cooling tower (assembly and supply) & $1.7 \%$ & 6.07 \\
Gas and fuel system & $1.9 \%$ & 6.83 \\
Electrical installations & $7.3 \%$ & 26.63 \\
Civil works and land conditioning & $15.9 \%$ & 57.92 \\
Control systems & $4.1 \%$ & 14.82 \\
External engineering required & $3.0 \%$ & 10.77 \\
Temporary works facilities & $2.1 \%$ & 7.80 \\
Personal expenses & $4.6 \%$ & 16.83 \\
Start-up & $5.1 \%$ & 18.63 \\
Initial expenses (permits, guarantees, etc.) & $0.9 \%$ & 3.11 \\
Total & $100 \%$ & 365 \\
\hline
\end{tabular}

Gas turbines are the most expensive equipment, with the highest fraction of initial investment. Civil works and steam turbines are the other two main parts of Capital Expenditures CAPEX.

To define Operational Expenditures is required an estimation of operational profile of the plant. For this estimation, and due to the difficulty to a more accurate estimation, operational costs have been estimated from a similar plant in terms of relative weights. Total Expenses include fuel expenses, which is the main concept, operation and maintenance, personnel and other general costs. Their estimated proportional weight is presented in Figure 16.

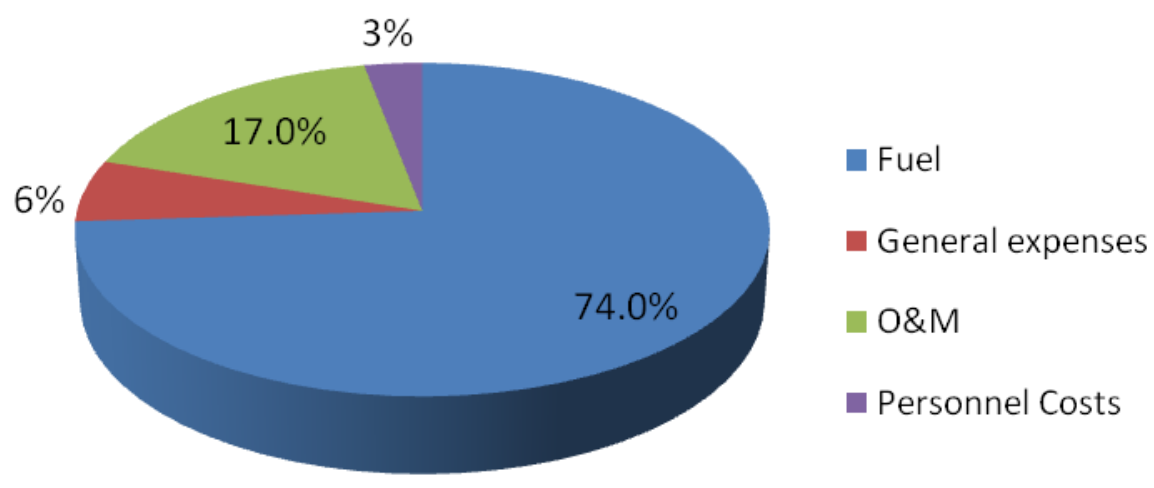

Figure 16. Operating expenses (OPEX) percentage of the CCP plant.

Fuel price, average price at $€ 0.034 / \mathrm{kWh}$ of thermal energy released by the fuel, has been considered.

The profitability of the investment project is quantitatively evaluated considering the Net Present Value NPV. It allows to evaluate short, medium and long-term investments It is defined as:

$$
\mathrm{VAN}=\sum_{t=1}^{n} \frac{V_{t}}{(1+k)^{t}}-I_{0}
$$

where $V_{t}$ are the cash flows in period $t$ that will have to be calculated; $n$ is the number of years that we have considered in our time horizon and $t$ in index for each year; $k$ is the discount rate or capital cost and $I_{0}$ is the initial investment.

Another parameter considered is the Internal Rate of Return (IRR). When the IRR is equal to the interest rate, the investor is indifferent between making the investment or not. The two necessary conditions to accept the feasibility of the present CCPP examined are that: 
- the NPV assumes a positive value

- that the IRR is greater than the discount rate.

The breakdown of the calculation of the cash flows considered in the NPV formula for the 25 years of our case are developed. As shown in Table 14, in the economic evaluation analysis, four scenarios are considered. To obtain the best options and to understand for which range of plant working the investment should be more profitable, the utilization factor (defined as quotient between the hours of operation considered and the total hours of a year) has been varied from $90 \%$ to $50 \%$.

Table 14. Utilization factor for the different cases considered.

\begin{tabular}{ccc}
\hline & Utilization Factor & Operating Hours per Year \\
\hline Case 1 & 0.9 & 7884 \\
Case 2 & 0.7 & 6132 \\
Case 3 & 0.6 & 5256 \\
Case 4 & 0.5 & 4380 \\
\hline
\end{tabular}

In Table 15 are reported the values of the NPV and IRR for the different cases considered.

Table 15. NPV and IRR values for the different cases considered.

\begin{tabular}{lcc}
\hline & NPV (MM€) & IRR (\%) \\
\hline Case 1 & 137.379 & 14.122 \\
Case 2 & 119.455 & 13.914 \\
Case 3 & 80.991 & 13.686 \\
Case 4 & 47.356 & 13.516 \\
\hline
\end{tabular}

Results obtained highlight that the plant is more profitable the higher the utilization factor. As evident in Figure 17, the most profitable case is the option 1. The cases 2, 3 and 4 are respectively $13 \%, 41 \%$ and $66 \%$ less profitable than the first option (considering the NPV value, we can consider about 18, 56 and $90 \mathrm{MM} €$ less NPV).

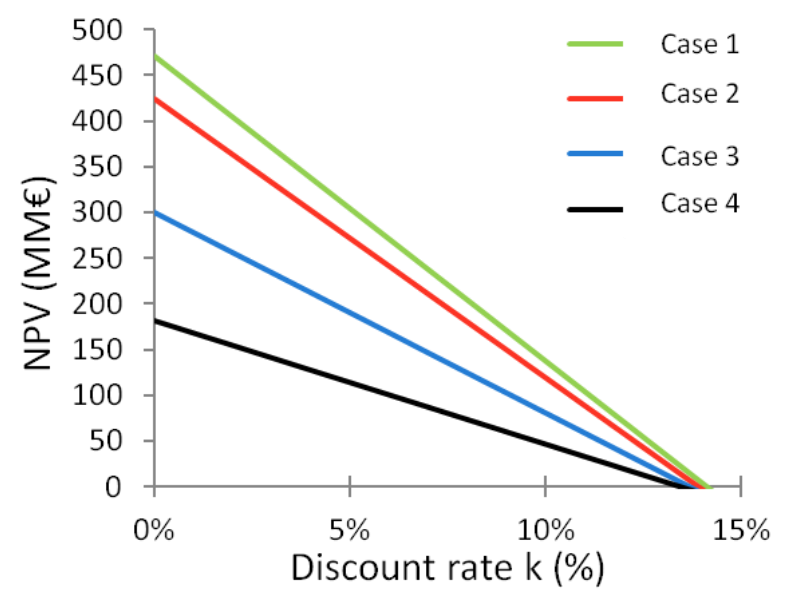

Figure 17. NPV for the obtained different options.

On the other hand, it is very interesting to identify the optimal utilization factor of the plant so that the investment is profitable. On the basis of the established financial model, it is obtained that when the plant operates less than $43 \%$ of the year's hours, the investment reaches an NPV negative so the investment is not convenient. In Figure 18 is shown the trend of NPV value considering the working hours of the plant in the year. 


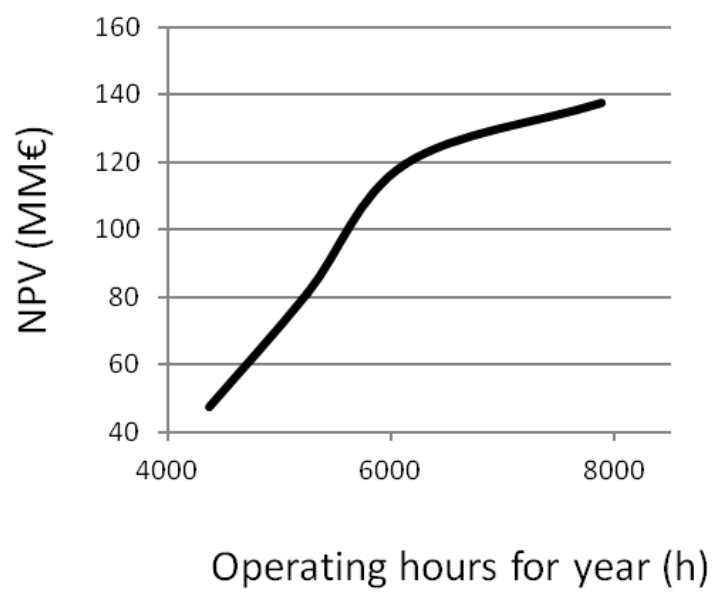

Figure 18. NPV in function of operating hours for year.

It is clear that the range that makes the investment profitable is between $70 \%$ and $43 \%$ of the operation of the plant throughout the year. It is also evident that the sale due to the sale of steam assumes a little weight with respect to income from the sale of electricity. In the CCPP, the higher cost is due to the need to purchase fuel. In fact, this cost exceeds, in most cases, both the initial investment and the operation and maintenance costs.

\section{Conclusions}

In this work are presented the analysis of potential energy, environmental and economic benefits of using alternative fuels for a CCPP located in India, in a region with a potential high availability of biomass.

The main conclusions of the analyses are:

- The performance of the combined cycle with operating the four different types of syngas have been estimated and compared with those of the cases of conventional natural gas.

- Among the four syngases analyzed, a better efficiency is achieved for syngas 1 (up to $54 \%$ ) in respect to the others. The higher efficiencies and lowest $\mathrm{CO}_{2}$ emissions are obtained fuelling with syngas 2 .

- Two operation modes have been considered, as CHP plant: considering steam exporting to a refinery and as a standalone power cycle, without exporting steam. Under these two operation modes, operation curves of the combined cycle are estimated for ambient parameters.

- The analysis is closed with an economic analysis to identify the effect of an annual utilization factor in power plant viability, to assess the different effects.

The results of this study can provide useful information to power plant engineers and operators, such as possible performance enhancement modifications to combined cycle power plants.

Author Contributions: Conceptualization, G.M. and R.C.; methodology, G.M.; software, B.F.V.-P., G.M.; validation, G.M., R.C., and C.M.M.; formal analysis, G.M.; investigation, G.M.; resources, G.M.; data curation, G.M., B.F.V.-P. and C.M.M.; writing — original draft preparation, G.M.; writing—review and editing, G.M. and R.C.; visualization, G.M. and C.M.M.; supervision, G.M., R.C.; project administration, R.C., G.M.; funding acquisition, C.M.M., G.M, R.C. All authors have read and agreed to the published version of the manuscript.

Funding: This research received no external funding.

Conflicts of Interest: The authors declare no conflict of interest. 


\section{References}

1. EPA. 2020. Available online: https://www.epa.gov/ghgemissions/inventory-us-greenhouse-gas-emissionsand-sinks (accessed on 12 February 2020).

2. European Climate Foundation. Roadmap 2050: A Practical Guide to a Prosperous, Low Carbon Europe: Technical and Economic Assessment; European Climate Foundation: Hague, The Netherlands, 2010; Volume I, Available online: https://www.roadmap2050.eu/attachments/files/Volume1_fullreport_PressPack.pdf (accessed on 21 October 2019).

3. European Commission. Energy RoadMap 2050; Publications Office of the European Union: Luxembourg, 2012.

4. Di Fraia, S.; Macaluso, A.; Massarotti, N.; Vanoli, L. Energy, exergy and economic analysis of a novel geothermal energy system for wastewater and sludge treatment. Energy Convers. Manag. 2019, 195, 533-547. [CrossRef]

5. Manni, M.; Coccia, V.; Nicolini, A.; Marseglia, G.; Petrozzi, A. Towards Zero Energy Stadiums: The case study of the Dacia Arena in Udine, Italy. Energies 2018, 11, 2396. [CrossRef]

6. Marseglia, G.; Rivieccio, E.; Medaglia, C.M. The dynamic role of Italian Energy strategies in the worldwide scenario. Kybernetes 2019, 48, 636-649. [CrossRef]

7. Calise, F.; Di Fraia, S.; Macaluso, A.; Massarotti, N.; Vanoli, L. A geothermal energy system for wastewater sludge drying and electricity production in a small island. Energy 2018, 163, 130-143. [CrossRef]

8. United Nations. Sustainable Development Goals. Available online: https://sustainabledevelopment.un.org/ sdgs (accessed on 7 September 2016).

9. Abdelrahim, A.; Brachi, P.; Ruoppolo, G.; Di Fraia, S.; Vanoli, L. An Experimental and Numerical Investigation on Biosolids Gasification: Equilibrium-based Modeling with Emphasis on Effects of Different Pretreatment Methods. Ind. Eng. Chem. Res. 2019. [CrossRef]

10. Cortellessa, G.; Arpino, F.; Di Fraia, S.; Scungio, M. Two-phase explicit CBS procedure for compressible viscous flow transport in porous materials. Int. J. Numer. Methods Heat Fluid Flow 2018. [CrossRef]

11. European Parliament. Directive 2004/8/EC of the European Parliament and of the Council of 11 February 2004; European Parliament: Brussels, Belgium, 2004; Available online: https:/eur-lex.europa.eu/legal-content/EN/ ALL/?uri=CELEX\%3A32004L0008 (accessed on 21 October 2019).

12. Patino, E.G.G.E.; Rivera, F.N. Global warming potential and net power output analysis of natural gas combined cycle power plants coupled with $\mathrm{CO}_{2}$ capture systems and organic Rankine cycles. J. Clean. Prod. 2019, 208, 11-18. [CrossRef]

13. Gangoli Rao, A.; Van den Oudenalder, F.S.C.; Klein, S.A. Natural gas displacement by wind curtailment utilization in combined-cycle power plants. Energy 2019, 168, 477-491.

14. Kotowicz, J.; Brzeczek, M. Analysis of increasing efficiency of modern combined cycle power plant: A case study. Energy 2018, 153, 90-99. [CrossRef]

15. Lizana, J.; Serrano-Jimenez, A.; Ortiz, C.; Becerra, J.A.; Chacartegui, R. Energy assessment method towards low-carbon energy schools. Energy 2018, 159, 310-326. [CrossRef]

16. Soltero, V.M.; Chacartegui, R.; Ortiz, C.; Velazquez, R. Potential of biomass district heating systems in rural areas. Energy 2018, 156, 132-143. [CrossRef]

17. Marseglia, G.; Medaglia, C.M.; Petrozzi, A.; Nicolini, A.; Cotana, F.; Sormani, F. Experimental tests and modeling on a CHP biomass plant. Energies 2019, 12, 2615. [CrossRef]

18. Blumberg, T.; Assara, M.; Morosukb, T.; Tsatsaronis, G. Comparative exergoeconomic evaluation of the latest generation of combined-cycle power plants. Energy Convers. Manag. 2017, 153, 616-626. [CrossRef]

19. Tica, A.; Gueguen, H.; Dumur, D.; Faille, D.; Davelaar, F. Design of a combined cycle power plant model for optimization. Appl. Energy 2012, 98, 256-265. [CrossRef]

20. Carcasci, C.; Cosi, L.; Ferraro, R.; Pacifici, B. Effect of a real steam turbine on thermoeconomic analysis of combined cycle power plants. Energy 2017, 138, 32-47. [CrossRef]

21. Kwon, H.M.; Kim, T.S.; Sohn, J.L.; Kang, D.W. Performance improvement of gas turbine combined cycle power plant by dual cooling of the inlet air and turbine coolant using an absorption chiller. Energy 2018, 163, 1050-1061. [CrossRef]

22. Di Fraia, S.; Figaj, R.D.; Massarotti, N.; Vanoli, L. An integrated system for sewage sludge drying through solar energy and a combined heat and power unit fuelled by biogas. Energy Convers. Manag. 2018, 171, 587-603. [CrossRef] 
23. Kotowicz, J.; Brzeczek, M. Comprehensive multivariable analysis of the possibility of an increase in the electrical efficiency of a modern combined cycle power plant with and without a $\mathrm{CO}_{2}$ capture and compression installations study. Energy 2019, 175, 1100-1120. [CrossRef]

24. Ibrahima, T.K.; Mohammed, M.K.; Awad, O.I.; Abdalla, A.N.; Basrawi, F.; Mohammed, M.N.; Najafif, G.; Mamat, R. A comprehensive review on the exergy analysis of combined cycle power plants. Renew. Sustain. Energy Rev. 2018, 90, 835-850. [CrossRef]

25. Mehrpooya, M. Conceptual design and energy analysis of novel integrated liquefied natural gas and fuel cell electrochemical power plant processes. Energy 2016, 111, 468-483. [CrossRef]

26. Boretti, A.; Al-Zubaidy, S. A case study on combined cycle power plant integrated with solar energy in Trinidad and Tobago. Sustain. Energy Technol. Assess. 2019, 32, 100-110. [CrossRef]

27. Binamer, A.; Al-Abdaliya, O. integrated solar combined cycle power plant: Case study of Kuwait, part I. Renew. Energy 2019, 131, 923-937. [CrossRef]

28. Martinez, S.; Michaux, G.; Salagnac, P.; Bouvier, J.L. Micro-combined heat and power systems (micro-CHP) based on renewable energy sources. Energy Convers. Manag. 2017, 154, 262-285. [CrossRef]

29. Ersayin, E.; Ozgener, L. Performance analysis of combined cycle power plants: A case study. Renew. Sustain. Energy Rev. 2015, 43, 832-842. [CrossRef]

30. Kotowicz, J.; Job, M.; Brzeczek, M. The characteristics of ultramodern combined cycle power plants. Energy 2015, 92, 197-211. [CrossRef]

31. Calise, F.; Dentice d'Accadia, M.; Libertini, L.; Vicidomini, M. Thermoeconomic analysis of an integrated solar combined cycle power plant. Energy Convers. Manag. 2018, 171, 1038-1051. [CrossRef]

32. Jahangiri, A.; Yahyaabadi, M.M.; Sharif, A. Exergy and economic analysis of using the flue gas injection system of a combined cycle power plant into the Heller Tower to improve the power plant performance. J. Clean. Prod. 2019, 233, 695-710. [CrossRef]

33. Kilani, N.; Khir, T.; Brahim, A.B. Performance analysis of two combined cycle power plants with different steam injection system design. Int. J. Hydrog. Energy 2017, 42, 12856-12864. [CrossRef]

34. Ganjehkaviri, A.; Mohd Jaafar, M.N.; Hosseini, S.E. Optimization and the effect of steam turbine outlet quality on the output power of a combined cycle power plant. Energy Convers. Manag. 2015, 89, 231-243. [CrossRef]

35. Koch, C.; Cziesla, F.; Tsatsaronis, G. Optimization of combined cycle power plants using evolutionary algorithms. Chem. Eng. Process. 2007, 46, 1151-1159. [CrossRef]

36. Liu, Z.; Karimi, A. Simulation of a combined cycle gas turbine power plant in ASPEN HYSYS. Energy Procedia 2019, 158, 3620-3625. [CrossRef]

37. Atnaw, S.M.; Sulaiman, S.A.; Yusup, S. Syngas production from downdraft gasification of oil palm fronds. Energy 2013, 61, 491-501. [CrossRef]

38. Goransson, K.; Soderlind, U.; He, J.; Zhang, W. Review of syngas production via biomass DFBGs. Renew. Sustain. Energy Rev. 2013, 15, 482-492. [CrossRef]

39. Kim, Y.S.; Lee, J.J.; Kim, T.S.; Sohn, J.L. Effects of syngas type on the operation and performance of a gas turbine in integrated gasification combined cycle. Energy Convers. Manag. 2011, 52, 2262-2271. [CrossRef]

40. Scarcelli, R. Challenges and opportunities for the use of natural gas in the light duty automotive field. In Proceedings of the ASME International Combustion Engine Division Fall Technical Conference, Vancouver, BC, Canada, 23-26 September 2012.

41. Marseglia, G.; Costa, M.; Catapano, F.; Sementa, P.; Vaglieco, B.M. Study about the link between injection strategy and knock onset in an optically accessible multi-cylinder GDI engine. Energy Convers. Manag. 2017, 134, 1-19. [CrossRef]

42. Chacartegui, R.; Sanchez, D.; Escalona, M.; Monje, B.; Sanchez, T. On the effects of running existing combined cycle power plants on syngas fuel. Fuel Process Technol. 2012, 103, 97-109. [CrossRef]

43. Chacartegui, R.; Sanchez, D.; Escalona, M.; Munoz, A.; Sanchez, T. Gas and steam combined cycles for low calorific syngas fuels utilisation. Appl. Energy 2013, 101, 81-92. [CrossRef]

44. Chacartegui, R.; Torres, M.; Sánchez, D.; Jiménez, F.; Muñoz, A.; Sánchez, T. Analysis of main gaseous emissions of heavy duty gas turbines burning several syngas fuels. Fuel Process. Technol. 2011, 92, 213-220. [CrossRef] 
45. Cotana, F.; Vittori, S.; Marseglia, G.; Medaglia, C.M.; Coccia, V.; Petrozzi, A.; Nicolini, A.; Cavalaglio, G. Pollutant emissions of a biomass gasifier inside a multifuel energy plant. Atmos. Pollut. Res. 2019, 10, 2000-2009. [CrossRef]

46. Ligang, Z.; Edward, F. Comparison of shell, texaco, BGL and KRW gasifiers as part of IGCC plant computer simulations. Energy Convers. Manag. 2005, 46, 1767-1779.

47. Szwaja, S.; Kovacs, V.B.; Bereczky, A.; Penninger, A. Sewage sludge producer gas enriched with methane as a fuel to a spark ignited engine. Fuel Process Technol. 2013, 110, 160-166. [CrossRef]

48. AlNouss, A.; McKay, G.; Al-Ansari, T. Production of syngas via gasification using optimum blends of biomass. J. Clean. Prod. 2020, 242, 118499. [CrossRef]

49. Inayat, M.; Sulaiman, S.A.; Kurnia, J.C.; Shahbaz, M. Effect of various blended fuels on syngas quality and performance in catalytic co-gasification: A review. Renew. Sustain. Energy Rev. 2019, 105, 252-267. [CrossRef]

50. Kim, Y.S.; Lee, J.J.; Cha, K.S.; Kim, T.S.; Sohn, J.L.; Joo, Y.J. Performance analysis of a syngas-fed gas turbine considering the operating limitations of its components. Appl. Energy 2010, 87, 1602-1611. [CrossRef]

51. Sánchez, D.; Chacartegui, R.; Muñoz de Escalona, J.M.; Sanchez, T. Performance analysis of a heavy duty combined cycle power plant burning various syngas fuels. Int. J. Hydrog. Energy 2010, 35, 337-345. [CrossRef]

52. Hagos, F.Y.; Aziz, A.R.A.; Sulaiman, S.A. Methane enrichment of syngas $\left(\mathrm{H}_{2} / \mathrm{CO}\right)$ in a spark-ignition direct injection engine: Combustion, performance and missions comparison with syngas and Compressed Natural Gas. Energy 2015, 90, 2006-2015. [CrossRef]

53. Neto, A.F.G.; Marques, F.C.; Amador, A.T.; Ferreira, A.D.S.; Neto, A.M.J.C. DFT and canonical ensemble investigations on the thermodynamic properties of Syngas and natural gas/Syngas mixture. Renew. Energy 2019, 130, 495-509. [CrossRef]

54. Ran, Z.; Hariharan, D.; Lawler, B.; Mamalis, S. Experimental study of lean spark ignition combustion using gasoline, ethanol, natural gas, and syngas. Fuel 2019, 235, 530-537. [CrossRef]

55. Piemsinlapakunchon, T.; Paul, C.M. Effects of fuel compositions on the heat generation and emission of syngas/producer gas laminar diffusion flame. Int. J. Hydrog. Energy 2019, 44, 18505-18516. [CrossRef]

56. Nadaleti, W.C.; Przybyl, G. SI engine assessment using biogas, natural gas and syngas with different content of hydrogen for application in Brazilian rice industries: Efficiency and pollutant emissions. Int. J. Hydrog. Energy 2018, 43, 10141-10154. [CrossRef]

57. Nadaleti, W.C.; Przybyla, G.; Ziolkowski, L.; Filho, P.B. Analysis of emissions and combustion of typical biofuels generated in the agroindustry sector of Rio Grande do Sul State e Brazil: Bio75, syngas and blends. J. Clean. Prod. 2019, 208, 988-998. [CrossRef]

58. Chein, R.Y.; Yu, C.T.; Wang, C.C. Numerical simulation on the effect of operating conditions and syngas compositions for synthetic natural gas production via methanation reaction. Fuel 2016, 185, 394-409. [CrossRef]

59. Jozwiak, P.; Hercog, J.; Kiedrzynska, A.; Badyda, K. CFD analysis of natural gas substitution with syngas in the Industrial Fornace. Energy 2019, 179, 593-602. [CrossRef]

60. Donohoe Heufer, K.A.; Aul, C.J.; Petersen, E.L.; Bourque, G.; Gordon, R.; Curran, H.J. Influence of steam dilution on the ignition of hydrogen, syngas and natural gas blends at elevated pressures. Combust. Flame 2015, 162, 1126-1135. [CrossRef]

61. Current Status. 2020. Available online: https://mnre.gov.in/bio-energy/current-status (accessed on 9 January 2020).

62. Ko, S.; Lautala, P.; Handler, R.M. Securing the feedstock procurement for bioenergy products: A literature review on the biomass transportation and logistics. J. Clean. Prod. 2018, 200, 205-218. [CrossRef]

63. Hiloidhari, M.; Baruah, D.C.; Kumari, M.; Kumari, S.; Thakur, I.S. Prospect and potential of biomass power to mitigate climate change: A case study in India. J. Clean. Prod. 2019, 220, 931-944. [CrossRef]

64. Kumar, A.; Kumar, N.; Baredar, P.; Shukla, A. A review on biomass energy resources, potential, conversion and policy in India. Renew. Sustain. Energy Rev. 2015, 45, 530-539. [CrossRef]

65. National Capital Region India. Available online: https://en.wikipedia.org/wiki/National_Capital_Region_ (India) (accessed on 16 October 2019).

66. Biomass Energy in India. Available online: https://indien.um.dk/en/innovation/sector-updates/renewableenergy/biomass-energy-in-india/ (accessed on 9 November 2019).

67. Wu, J.; Fang, Y.; Wang, Y. Combined Coal Gasification and Methane Reforming for Production of Syngas in a Fluidized-Bed Reactor. Energy Fuels 2005, 19, 512-516. [CrossRef] 
68. Ouyang, Z.; Guo, Z.; Duan, D.; Song, X.; Yu, X. Experimental Study of Coal Gasification Coupling with Natural Gas Autothermal Re-Forming for Synthesis Gas Production. Industr. Eng. Chem. Res. 2005, 44, 279-284. [CrossRef]

69. Xiao, R.; Zhang, M.; Jin, B.; Huang, Y. High-Temperature Air/Steam-Blown Gasification of Coal in a Pressurized Spout-Fluid Bed. Energy Fuels 2006, 20, 715-720. [CrossRef]

70. Treviño, M. Tecnología de Gasificación Integrada en Ciclo Combinado GICC. Aplicación Real en España; Club Español de la Energía: Puertollano, Spain, 2003.

(C) 2020 by the authors. Licensee MDPI, Basel, Switzerland. This article is an open access article distributed under the terms and conditions of the Creative Commons Attribution (CC BY) license (http://creativecommons.org/licenses/by/4.0/). 